\title{
Size and Development of the Shadow Economies of 157 Worldwide Countries: Updated and New Measures from 1999 to 2013
}

Hassan Mai $^{1 *}$ and Schneider Friedrich ${ }^{2}$

${ }^{1}$ Department of Middle East Economics, Center of Near and Middle Eastern Studies (CNMS), Philipps-University of Marburg, Germany

${ }^{2}$ Department of Economics, Johannes Kepler University of Linz, Austria

\begin{abstract}
This paper is a first attempt to study the size and development of the shadow economies of 157 countries between 1999 and 2013. Using a MIMIC model, we find that higher tax and regulatory burden, unemployment and self-employment rates are drivers of the shadow economy, meaning that an increase in these causal variables increases the shadow economy. Our result also confirms previous findings of Friedrich Schneider, Andreas Buehn and Claudia Montenegro. The estimated average of informality of 157 countries around the world, including developing, eastern European, central Asian and high income OECD countries averaged over 1999 to 2013 is $33.77 \%$ of official GDP. A critical discussion about the size of these macro-estimates comes to the conclusion that most likely the "true" shadow economy of these countries is only $69 \%$ of their estimated macro-MIMIC-values.
\end{abstract}

Keywords: Shadow economies of 157 countries; Quality of institutions; Tax burden; MIMIC model

\section{Introduction}

Many studies have investigated the dynamic nature of the shadow economy, yet there is no unified definition of the shadow economy. Generally, the shadow economy is known by different names such as the hidden, grey, black or informal economy. All these synonyms refer to some type of shadow economic activities. The shadow economy includes all economic activities that are deliberately hidden from official authorities for various reasons. These vary from being monetary, to regulatory, to institutional reasons. Monetary reasons include avoiding paying taxes and/or social security contributions, regulatory reasons include avoiding governmental bureaucracy or the burden of regulatory framework, while institutional reasons include corruption, low quality of political institutions and weak rule of law.

Given the purpose of our study, the shadow economy reflects mostly the legal economic and productive activities that, if recorded, would contribute to national GDP. Therefore, the definition of the shadow economy in our study tries to avoid illegal or criminal activities, do-it-yourself, charitable or household activities ${ }^{1}$. Whether we succeed in doing this is an open question, because the traditional drivers of a shadow economy (e.g. tax and regulatory burden, unemployment, etc.) are quite often also responsible for some crime activities (e.g. smuggling) and do-it-yourself actions. Although the shadow economy is unobserved and it is very challenging to reach a unified definition, it is important to define the shadow economy in view of the current study in order to correctly model the unobserved economy by including variables that lead to and reflect the existence of the shadow economy. As our goal is to estimate the size of the shadow economy in a roughly comparable way over countries, we focus mainly on the major macroeconomic variables that affect individuals' motivation to participate in market-based informal activities.

The existence of the shadow economy in a country leads to diverse effects that influence the official economic and social life of the country. The shadow economy creates inefficiencies in the labor market, is a source of resource allocation distortions, leads to biases in official indicators such as an upward bias in the unemployment

${ }^{1}$ Of course, we are aware that there are overlapping areas, like prostitution, illegal construction firms, compare e.g. Williams and Schneider (2016). rate, and/or creates a vicious cycle of continuous increases in the tax base. However, the shadow economy is not necessarily seen as a foe to the overall economy. Individuals spend income earned in the shadow economy later in the formal economy, leading to stimulating effects. For instance, two thirds of the income earned in the shadow economy is later spent in the formal economy [1-3]. In developing countries, companies are able to either buy or manufacture secondary inputs in the shadow economy which then helps the overall economy by creating some jobs that would otherwise would be not be available. Also, individuals can buy cheaper goods or services from the shadow economy. Last but not least, the shadow economy is a safe harbor in times of turmoil and recession, acting like an employer of last resort.

The purpose of our study is twofold: First, to estimate the size of the shadow economy of 157 countries all over the world measured as a percentage of GDP by using a MIMIC model from 1999 to 2013. Second, a critical discussion about the size of the macro-estimates of these shadow economies follows, suggesting a correction factor in order to reach the "true" size. To our knowledge this has not been done before.

Our paper is organized as follows: In section 4, the MIMIC model as well as the theoretical background of the exogenous variables is explained. The MIMIC estimation of the size of the shadow economy is shown in section 5. Section 6 shows the results and implications including a critical discussion about the size of the shadow economy from these macro-estimates. Finally, section 7 concludes.

\section{Measuring the Shadow Economy}

There are different methods that can be applied to measure the size and the development of the shadow economy over time. These include

*Corresponding author: Hassan Mai, Department of Middle East Economics, Center of Near and Middle Eastern Studies (CNMS), Philipps-University of Marburg Germany, Tel: 0043-732-2468-7340; E-mail: mai.hassan@staff.uni-marburg.de

Received September 08, 2016; Accepted September 16, 2016; Published September 21, 2016

Citation: Hassan Mai, Schneider Friedrich (2016) Size and Development of the Shadow Economies of 157 Worldwide Countries: Updated and New Measures from 1999 to 2013. J Glob Econ 4: 218. doi: 10.4172/2375-4389.1000218

Copyright: (C) 2016 Hassan Mai, et al. This is an open-access article distributed under the terms of the Creative Commons Attribution License, which permits unrestricted use, distribution, and reproduction in any medium, provided the original author and source are credited. 
direct methods such as survey methods, indirect methods known as indicator approaches, and lastly the model as latent approach which is a statistical method such as the MIMIC model ${ }^{2}$.

The MIMIC model is a special type of structural equation modelling (SEM) that is widely applied in psychometrics and social science research and is based on the statistical theory of unobserved variables developed in the 1970s by Zellner [4] and Joreskog et al. [5]. The MIMIC model is a theory-based approach to confirm the influence of a set of exogenous causal variables on the latent variable (shadow economy), and also the effect of the shadow economy on macroeconomic indicator variables [6]. At first, it is important to establish a theoretical model explaining the relationship between the exogenous variables and the latent variable. Therefore, the MIMIC model is considered to be a confirmatory rather than an explanatory method $[7,8]$. The hypothesized path of the relationships between the observed variables and the latent shadow economy based on our theoretical considerations is depicted in the following Figure 1.

The pioneers to apply the MIMIC model to measure the size of the shadow economy in 17 OECD countries were Frey et al. [9]. Following them, various scholars like Tafenau et al. [10], Tedds [11], Schneider et al. [7], Dell'Anno [12], Hassan et al. [13], Buehn et al. [14], Farzanegan [6], and Chaudhuri et al. [15] applied the MIMIC model to measure the size of the shadow economy.

Formally, the MIMIC model has two parts: the structural model and the measurement model. The structural model shows that the latent variable $\eta$ is linearly determined by a set of exogenous causal variables which can be illustrated as follows:

$$
\eta=\gamma^{\prime} \chi+\varsigma
$$

Where,

$\chi$ is a vector of causal variables, $\gamma$ is a vector of scalars, $\eta$ is the latent variable (shadow economy) and $\varsigma$ is a structural disturbance term.

The measurement model which links the shadow economy with the set of selected indicators is specified by:

$$
y=\lambda \eta+\varepsilon
$$

Where, $y$ is a vector of indicator variables, and $\lambda$ is a vector of loading factors to represent the magnitude of the expected change for a unit change in the latent variable $\eta$. The $\varepsilon$ is the measurement error term.

The MIMIC model simultaneously takes into account different causes and indicators that directly influence the development of the size of the shadow economy over time. In the following, some theoretical considerations of the different cause and indicator variables are made.

\section{Causal variables ${ }^{3}$}

Tax burden: It is widely accepted in the literature that the most important cause leading to the proliferation of the shadow economy is the tax burden. The higher the overall tax burden, the stronger the incentives to operate informally in order to avoid paying taxes. However, it is important to note that in countries where the tax base is large, the shadow economy may not be large and this can be explained by the good institutional framework that such a country enjoys ${ }^{4}$. As a result of this phenomenon, we include in our model institutional

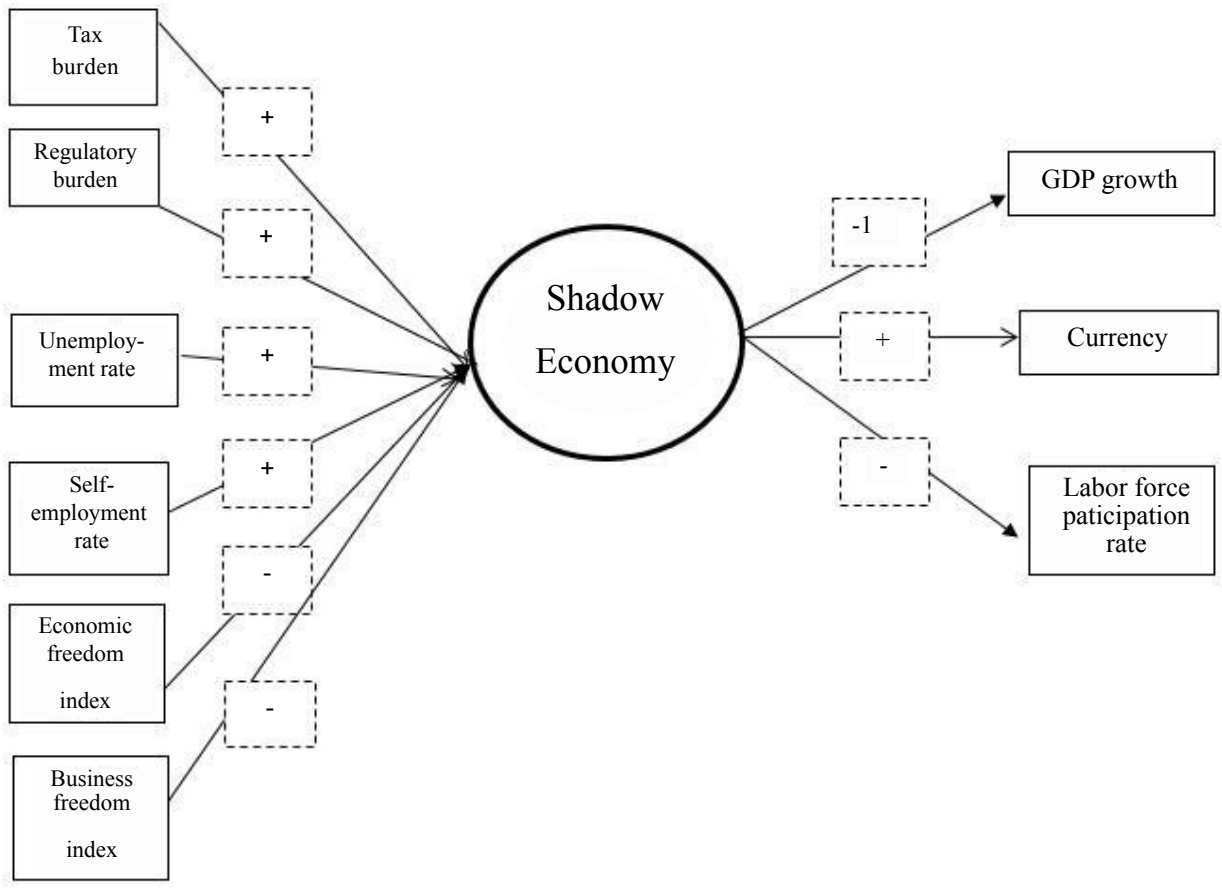

Figure 1: Hypothesized MIMIC path for estimating the shadow economy.

${ }^{2}$ As there is available a huge literature about the various methods available to measure a shadow economy, a detailed overview about it as well as the problems using these methods (including the MIMIC method) are not discussed here. See e.g. Schneider and Enste (2002), Feld and Schneider (2010), Schneider, Büehn and Montenegro (2010), Schneider $(2010,2015)$, Schneider and Williams (2013), Williams and Schneider (2016).
${ }^{3}$ We are aware that there are more causal variables than the five included here, but due to a lack of data we could include only the five shown.

${ }^{4}$ The explanation is the following: When taxpayers/voters get a high quality of goods and services from the state, they are willing to pay taxes for these publicly provided goods and services. 
quality variables such as economic freedom, and business freedom indices. A statistically significant and positive effect of the tax burden on the development of the shadow economy has been found by various studies including Tanzi [16], Alañón et al. [17], Schneider [2], Buehn [18], and Hassan et al. [13]. In our MIMIC model, tax burden is proxied by total tax revenues as a percentage of GDP.

Hypothesis 1: The higher the tax burden, the larger the size of the shadow economy, ceteris paribus.

Regulatory burden: Intensive regulation leads to bureaucracy, limits business freedom, and decreases entrepreneurship entry, thus leading to higher motivation to participate in the shadow economy. Buehn et al. [19], Johnson et al. [20], and Loayza NV [21] concluded that regulatory burden leads to larger sizes of shadow economy. In our MIMIC model, regulatory burden is proxied by total government spending as a percentage of GDP.

Hypothesis 2: The more intensive the regulatory burden is, the larger the size of the shadow economy, ceteris paribus.

Unemployment rate: Unemployment has an ambiguous effect on the development of the shadow economy. On one hand, some authors including Schneider et al. [7] and Dell'Anno et al. [22] found that higher unemployment rates pushed individuals to operate in the shadow economy to find jobs. On the other hand, it is argued that when the overall economy is in steady recession and unemployment continuously increases, unemployment does not play a major role in affecting the size of the shadow economy. For instance, in Egypt, unemployment does not affect the development of the shadow economy over time because the availability of jobs in both the informal and formal economy is limited as there is continuous contraction of the overall economy and the unemployment rate is always high [13]. However, we assume that, in general, unemployment creates incentives to work in the shadow economy. In the MIMIC model, the unemployment rate is measured by total unemployment as a percentage of the labor force.

Hypothesis 3: The higher the unemployment, the larger the size of the shadow economy, ceteris paribus.

Self-employment rate: It is accepted that self-employment has a positive and significant effect on the size of the shadow economy, as concluded by various authors like Dell'Anno et al. [22], Tedds [11] and Hassan and Schneider [13]. It is expected that the self-employed are highly motivated to avoid complying with tax regulations because they have a great number of legal and "illegal" tax deductions. Also, they enjoy direct business relationships with customers, which allows them to bargain with their customers to reach "tax saving" agreements. Last, the self-employed are more likely to employ irregular and informal employees because they have weak and lesser auditing controls relative to bigger and more formal organizations. In our model, selfemployment is measured by total self-employed as a percentage of total employed.

Hypothesis 4: The higher the self-employment rate, the larger the size of the shadow economy, ceteris paribus.

Institutional quality: In addition to the macroeconomic variables, it is critical to examine the effect of the quality of institutions on the size and development of the shadow economy. Various authors have studied the quality of public institutions as a determining variable of the shadow economy. Based on different studies, Schneider [2], Razmi et al. [23] and Hassan and Schneider [13] concluded that the quality of institutions significantly affects people's motivations to participate in the shadow economy.
It is expected that efficient regulation and good rule of law, freedom to start a new business, secure property rights and enforceable contracts increase the benefits of remaining in the official economy and increase the costs of informality. However, corruption, bureaucracy and regulatory burden act as a barrier to conduct and open a new business in the formal economy, pushing individuals to operate in the shadow economy.

As a proxy of institutional quality in our model, we use the economic freedom index and the business freedom index provided by the Heritage Foundation. These indices range from a scale of 0 to 100 with 100 equalling the freest environment.

Hypothesis 5: The higher the economic freedom index, the smaller the size of the shadow economy, ceteris paribus.

Hypothesis 6: The higher the business freedom index, the smaller the size of the shadow economy, ceteris paribus.

In order to investigate whether there is an interaction between a good institutional framework and the tax system, we also include an interaction variable, which is (economic freedom index) $\times(\operatorname{tax}$ burden). As in footnote 4 and under point 4.1 .1 we want to test that under a good institutional framework people are willing to pay higher taxes than under a pure institutional framework with bad governance and high corruption. For this interaction variable we expect a negative sign.

Hypothesis 7: The better the institutional framework the more people are willing to pay taxes and work less in the shadow economy, ceteris paribus.

A problem: Considering these causal factors as main driving forces for the shadow economy, the following problem arises:

All these causal factors, but especially;

- Tax burden

- Regulation

- Unemployment

are major driving forces for smuggling, do-it-yourself activities ${ }^{5}$ and neighbours' help, too. This means, that in the MIMIC and currency demand estimations these activities are (at least partly) included hence, these estimations are considerably higher than the "true" shadow economy estimates.

\section{Indicator variables}

After considering the different causes that affect the size of the shadow economy, the MIMIC model requires the specification of different indicators that reflect the existence of the shadow economy.

Formal economy: It is widely accepted that there is a negative relationship between the shadow economy and the formal economy as the shadow economy absorbs resources and human capital from the formal economy creating a contraction in the formal economy. Several scholars including Schneider et al. [7], Loayza [21], Buehn [19], Schneider [24], Buehn [14] as well as Hassan et al. [13] found a negative and significant relationship between the shadow economy and formal economy. In our empirical model, the formal economy is proxied by GDP growth. Since the shadow economy is not directly measured, GDP growth is our reference variable in our MIMIC model and is

${ }^{5}$ The amount of do-it-yourself activities has been measured for Germany by Buehn Karmann and Schneider (2009) using also the MIMIC approach. Do-it-yourself activities reached $4.2 \%$ of GDP in 1970 and $5 \%$ in 2005 ; including bought material. The major causal driver for do-it-yourself activities was unemployment. 
assigned the value of 1 .

Hypothesis 7: The larger the size of the shadow economy, the lower the official GDP growth, ceteris paribus.

Currency/cash outside banks: The shadow economy is expected to be reflected in an economy by the increase in the currency in circulation because individuals who participate in informal activities prefer to pay for their informal activities in cash rather than with credit/debit cards, checks or bank transactions in order to avoid any evidence of trace by official authorities. Studies by various scholars such as Alañón et al. [17], Buehn [18], Dell'Anno et al. [22], Schneider et al. [7] and Hassan and Schneider [13] concluded that there is a significant and positive relationship between the size of the shadow economy and currency held by the public. Therefore, in the MIMIC model, currency is proxied by the ratio of M1 over M2.

Hypothesis 8: The larger the size of the shadow economy, the more money held by the public, ceteris paribus.

Labor force participation rate: There is controversy over whether changes in the participation rate of registered labor reflect changes in the shadow economy. On one hand, the shadow economy absorbs resources from the formal economy, as human capital shifts to the shadow economy and hence moves human resources from the formal economy to the informal economy. Several authors, including Bajada et al. [25], Dell'Anno et al. [22] and Schneider et al. [7] included labor force rate as an indicator to mirror the existence of the shadow economy. Therefore, we expect that there is a negative relationship between labor force and the shadow economy. On the other hand, it is counter argued that a decline in the labor force participation rate does not truly reflect informal shadow economic activities because the registered official labor force does not totally withdraw itself from the formal economy and thus might conduct informal activities during holidays, after working hours, or on weekends. Dell'Anno [12] found evidence of a positive significant relationship between the shadow economy and labor force participation for the case of Portugal.

In our model, the labor force participation rate is measured by the total of workforce as a percentage of total population. If we find that there is a negative relationship, then registered official labor shifts from the formal economy to the informal economy, but based on our estimations, labor force participation rate is a weak indicator of the shadow economy.

Hypothesis 9: The larger the size of the shadow economy, the lower the official labor force participation rate, ceteris paribus.

\section{Estimation of the Size of the Shadow Economy}

After establishing an economic theoretical model explaining the expected relationship between the latent variable and the observed variables as shown in Figure 1, the MIMIC model tests these theoretical considerations and may confirm the hypothesized relationships between the latent variable $\eta$ (shadow economy) and its causes and indicators. The maximum likelihood method (ML) will be applied to estimate the parameters of the MIMIC model. Then, the time series index of the size of the shadow economy is estimated. This time series MIMIC index based on equation (1) is calculated by multiplying the coefficients of the significant causal variables with the respective time series. The MIMIC model produces only an index of the trend of the size of the shadow economy; meaning that it only tells us about changes in the ratio of the size of the shadow economy from year to year. Thus an additional step is required to calibrate this index in order to calculate the size of the shadow economy as a percentage of GDP. This step is called the benchmarking step and it requires an exogenous estimate of the size of the shadow economy at a certain point in time. For our case, the exogenous size of the shadow economy for the different countries in our sample is extracted from Schneider et al. [7]. The benchmarking procedure and the MIMIC methodology are explained in the appendix (A1 and A2).

It is important to note that in the MIMIC model estimation we need to fix an indicator variable in the measurement equation (2) [26]. This is required in order to have a reference variable to set a unit of measurement (i.e., as percentage of GDP) for the shadow economy because it is, by nature, unobserved. In our MIMIC estimations, the reference variable is GDP growth in percentage points and the associated sign to our reference variable is -1 . The strategy to determine the sign of the reference variable is called 'reductio ad absurdum' which is based on our theoretical assumptions and theory regarding the expected relationship between the exogenous variables and the unobserved shadow economy [22].

\begin{tabular}{|c|c|c|c|c|c|}
\hline $\begin{array}{l}\text { Variables/spec } \\
\text { Causes }\end{array}$ & $\underset{5-1-3}{\text { MIMIC } 1}$ & $\begin{array}{c}\text { MIMIC } 2 \\
4-1-3\end{array}$ & $\begin{array}{l}\text { MIMIC } 3 \\
4-1-2\end{array}$ & $\begin{array}{c}\text { MIMIC } 4 \\
3-1-3\end{array}$ & $\begin{array}{c}\text { MIMIC } 5 \\
5-1-3\end{array}$ \\
\hline Tax burden & $\begin{array}{l}0.15^{\star *} \\
(2.07)\end{array}$ & $\begin{array}{l}0.15^{\star *} \\
(2.07)\end{array}$ & $\begin{array}{l}0.15^{\star} \\
(2.06)\end{array}$ & $\begin{array}{c}0.34^{* * *} \\
(2.80)\end{array}$ & $\begin{array}{l}0.17^{* *} \\
(2.21)\end{array}$ \\
\hline $\begin{array}{l}\text { Regulatory } \\
\text { burden }\end{array}$ & $\begin{array}{c}0.29^{\star \star *} \\
(2.74)\end{array}$ & $\begin{array}{c}0.29^{* \star \star} \\
(2.74)\end{array}$ & $\begin{array}{l}0.29^{\star \star *} \\
(2.73)\end{array}$ & & $\begin{array}{c}0.29^{* \star *} \\
(0.10)\end{array}$ \\
\hline $\begin{array}{l}\text { Unemployment } \\
\text { rate (first difference) }\end{array}$ & $\begin{array}{c}0.53^{\star * *} \\
(2.87)\end{array}$ & $\begin{array}{c}0.53^{\star * *} \\
(2.87)\end{array}$ & $\begin{array}{l}0.52^{* * *} \\
(2.86)\end{array}$ & & $\begin{array}{c}0.55^{* \star *} \\
(2.95)\end{array}$ \\
\hline $\begin{array}{l}\text { Economic } \\
\text { Freedom Index } \\
\text { (first difference) }\end{array}$ & $\begin{array}{l}-0.09^{*} \\
(-1.90)\end{array}$ & $\begin{array}{l}-0.10^{*} \\
(-1.97)\end{array}$ & $\begin{array}{l}-0.09^{* *} \\
(-1.93)\end{array}$ & $\begin{array}{c}-0.11 \\
(-1.64)\end{array}$ & $\begin{array}{c}-0.06 \\
(-1.34)\end{array}$ \\
\hline $\begin{array}{l}\text { Business } \\
\text { Freedom Index } \\
\text { (first difference) }\end{array}$ & $\begin{array}{l}-0.007 \\
(-0.19)\end{array}$ & & & & \\
\hline $\begin{array}{l}\text { Tax } \\
\text { burden*economic } \\
\text { freedom index }\end{array}$ & & & & $\begin{array}{c}-0.25^{\star \star *} \\
(-2.63)\end{array}$ & $\begin{array}{l}-0.15^{\star *} \\
(-2.32)\end{array}$ \\
\hline \multicolumn{6}{|l|}{ Indicators } \\
\hline GDP growth & $\begin{array}{l}-1^{* * *} \\
(-2.62)\end{array}$ & $\begin{array}{l}-1^{* * *} \\
(-2.97)\end{array}$ & $\begin{array}{l}-1^{* * *} \\
(2.55)\end{array}$ & $\begin{array}{l}-1^{* * *} \\
(-2.93)\end{array}$ & $\begin{array}{l}-1^{* * *} \\
(-3.07)\end{array}$ \\
\hline $\begin{array}{l}\text { Currency } \\
\text { (first difference) }\end{array}$ & $\begin{array}{l}0.09^{\star *} \\
(2.49)\end{array}$ & $\begin{array}{l}0.09^{\star *} \\
(2.49)\end{array}$ & $\begin{array}{c}0.09^{* * *} \\
(2.55)\end{array}$ & $\begin{array}{l}0.12^{* *} \\
(2.23)\end{array}$ & $\begin{array}{l}0.10^{* *} \\
(2.57)\end{array}$ \\
\hline $\begin{array}{l}\text { Labor force rate } \\
\text { (first difference) }\end{array}$ & $\begin{array}{c}-0.02 \\
(-0.54)\end{array}$ & $\begin{array}{c}-0.02 \\
(-0.55)\end{array}$ & & $\begin{array}{l}-0.03 \\
(-075)\end{array}$ & $\begin{array}{l}-0.02 \\
(-0.58)\end{array}$ \\
\hline Chi^2 (pvalue) & $\begin{array}{c}12.12 \\
(0.2770)\end{array}$ & $\begin{array}{c}11.46 \\
(0.1768)\end{array}$ & $\begin{array}{c}5.44 \\
(0.1423)\end{array}$ & $\begin{array}{c}8.79 \\
(0.1858)\end{array}$ & $\begin{array}{c}13.09 \\
(0.2187)\end{array}$ \\
\hline GFI & 0.94 & 0.94 & 0.97 & 0.86 & 0.94 \\
\hline CFI & 0.988 & 0.972 & 0.985 & 0.945 & 0.977 \\
\hline CD & 0.461 & 0.460 & 0.438 & 0.201 & 0.514 \\
\hline RMSEA & 0.010 & 0.014 & 0.019 & 0.015 & 0.012 \\
\hline Degrees of freedom & 35 & 27 & 20 & 20 & 35 \\
\hline $\begin{array}{l}\text { Number of } \\
\text { observations }\end{array}$ & 2,198 & 2,198 & 2,198 & 2,198 & 2,198 \\
\hline Number of countries & 157 & 157 & 157 & 157 & 157 \\
\hline
\end{tabular}

Notes: Absolute z-statistics are reported in parentheses. *, **, ${ }^{* *}$ denote significance at 10,5 and $1 \%$ significance levels. Goodness of fit index (GFI): values closer to 0.90 reflect a perfect fit. CFI: when the comparative fit index is closer to one, it indicates a good model fit. SRMR: The values less than 0.08 indicate a good model fit. Coefficient of Determination (CD): A perfect fit corresponds to a $C D=1$ (Kline, 2011). Degrees of freedom $=0.5(p+q)(p+q+1)$-t, where $p=$ number of causes, $q=$ number of indicators, $\mathrm{t}=$ number of free parameters. Source: Own calculations.

Table 1: MIMIC estimation of the size of the shadow economy from 1999 to 2013 yearly data. 
In our MIMIC estimations, we use annual data from 1999 to 2013 for the 157 countries in our sample. Variables and sources are defined in the appendix table (A1). As presented in Table 1, various MIMIC specifications have been run in order to estimate the magnitude and the effect of different causal variables on the size of the shadow economy for the 157 countries all over the world.

As indicated in Tables 1 and 2, the GDP growth is our reference variable and is assigned the value of -1 in all specifications. We started with a general specification testing for significance of all of the causal variables [27,28]. Considering the result of our MIMIC estimations in Table 1 we clearly see that the tax burden has a positive (theoretically expected) sign and is statistically significant at the $5 \%$ confidence level. The regulatory burden variable (size of government) has also the theoretically expected sign and is highly statistically significant at the $1 \%$ confidence level. The estimated coefficient of the unemployment rate is also highly statistically significant and has the expected positive sign. The economic freedom index has the expected negative sign and is statistically significant at the $10 \%$ confidence level. The business freedom index is not statistically significant. Our interaction variable (tax burden) $\times$ (economic freedom index) has the expected negative

\begin{tabular}{|c|c|c|c|}
\hline Variables/specification & $\begin{array}{c}\text { MIMIC } 1 \\
6-1-2\end{array}$ & $\begin{array}{l}\text { MIMIC } 2 \\
5-1-2\end{array}$ & $\begin{array}{c}\text { MIMIC } 3 \\
4-1-2\end{array}$ \\
\hline \multicolumn{4}{|l|}{ Causes } \\
\hline Tax burden & $\begin{array}{l}0.08^{*} \\
(1.70)\end{array}$ & $\begin{array}{l}0.08^{*} \\
(1.70)\end{array}$ & $\begin{array}{l}0.07^{*} \\
(1.70)\end{array}$ \\
\hline Regulatory burden & $\begin{array}{c}0.26^{\star * *} \\
(3.04)\end{array}$ & $\begin{array}{c}0.26^{\star * *} \\
(3.04)\end{array}$ & $\begin{array}{c}0.24^{\star * *} \\
(2.82)\end{array}$ \\
\hline $\begin{array}{l}\text { Unemployment rate } \\
\text { (first difference) }\end{array}$ & $\begin{array}{l}0.43^{* * *} \\
(3.27)\end{array}$ & $\begin{array}{c}0.43^{* * *} \\
(3.27)\end{array}$ & $\begin{array}{c}0.41^{* * *} \\
(3.03)\end{array}$ \\
\hline $\begin{array}{l}\text { Self-employment rate } \\
\text { (first difference) }\end{array}$ & $\begin{array}{l}0.12^{\star *} \\
(2.20)\end{array}$ & $\begin{array}{l}0.10^{* *} \\
(2.20)\end{array}$ & $\begin{array}{l}0.10^{* *} \\
(2.14)\end{array}$ \\
\hline $\begin{array}{l}\text { Economic Freedom } \\
\text { Index (first difference) }\end{array}$ & $\begin{array}{l}-0.06^{*} \\
(-1.66)\end{array}$ & $\begin{array}{l}-0.06^{*} \\
(-1.74)\end{array}$ & \\
\hline $\begin{array}{l}\text { Business Freedom } \\
\text { Index (first difference) }\end{array}$ & $\begin{array}{l}-0.01 \\
(-0.38)\end{array}$ & & \\
\hline \multicolumn{4}{|l|}{ Indicators } \\
\hline GDP growth & $\begin{array}{l}-1^{* * *} \\
(-3.34)\end{array}$ & $\begin{array}{l}-1^{* * *} \\
(-3.33)\end{array}$ & $\begin{array}{l}-1^{* * *} \\
(-3.08)\end{array}$ \\
\hline Currency & $\begin{array}{c}0.11^{\star \star *} \\
(2.79)\end{array}$ & $\begin{array}{l}0.11^{* *} \\
(2.79)\end{array}$ & $\begin{array}{c}0.10^{* * *} \\
(2.59)\end{array}$ \\
\hline \multicolumn{4}{|l|}{ Fit statistics } \\
\hline Chi^2 (pvalue) & $\begin{array}{c}9.93 \\
(0.0773)\end{array}$ & $\begin{array}{c}9.66 \\
(0.0465)\end{array}$ & $\begin{array}{c}3.44 \\
(0.3282)\end{array}$ \\
\hline GFI & 0.96 & 0.96 & 0.98 \\
\hline CFI & 0.975 & 0.973 & 0.995 \\
\hline CD & 0.325 & 0.324 & 0.283 \\
\hline RMSEA & 0.025 & 0.029 & 0.010 \\
\hline Degrees of freedom & 35 & 27 & 20 \\
\hline Number of observations & 1,638 & 1,638 & 1,638 \\
\hline Number of countries & 117 & 117 & 117 \\
\hline
\end{tabular}

Notes: Absolute z-statistics are reported in parentheses. *, **, *** denote significance at 10,5 and $1 \%$ significance levels. Goodness of fit index (GFI): values closer to 0.90 reflect a perfect fit. CFI: when the comparative fit index is closer to one, it indicates a good model fit. SRMR: The values less than 0.08 indicate a good model fit. Coefficient of Determination (CD): A perfect fit corresponds to $C D=1(K$ line, 2011). Degrees of freedom $=0.5(p+q)(p+q+1)-t$, where $p=$ number of causes, $q=$ number of indicators, $t=$ number of free parameters.

Table 2: MIMIC estimation of the size of the shadow economy from 1999 to 2013 yearly data for the reduced sample. sign and is highly statistically significant. However, the economic freedom index is no longer statistically significant, with the z-statistic just dropping below the $10 \%$ significance level. Considering the indicators, GDP growth and currency rate have the expected sign and are highly statistically significant, while the labor force participation rate is found to be insignificant and thus a weak indicator for the shadow economy.

While in specifications MIMIC 2 and MIMIC 3 in Table 1, the insignificant business freedom index was removed in order to be able to determine the most important variables that lead to the existence as well as the development of the shadow economy in the different countries in our sample. The calibration of the size of the shadow economy is based on specification MIMIC 2 including four causal variables and three indicators that reflect the existence and lead to the proliferation of the shadow economy. The choice of MIMIC specification 2 (4-1-3) is based on the better fit statistics when compared to MIMIC specification 3 (4-1-2).

Furthermore, we have estimated other MIMIC specifications for a reduced sample of 117 countries that included self-employment as an additional causal variable to our set of causal variables in order to have an additional view and understanding of the major determinants of the shadow economy. As indicated in Table 2, we have also run different MIMIC specifications starting with a general specification including all six causal variables until we reached the best MIMIC specification indicating the significant causal variables that influence the development of the size of the shadow economy. If we consider again first the causal variables, we see that the tax burden, regulatory burden and unemployment rate have the expected positive sign and are statistically significant, at least at the $5 \%$ confidence level. Moreover, the self-employment rate has the expected positive sign and is statistically significant at the $5 \%$ confidence level, as well as the economic freedom index $[29,30]$.

To summarize, the signs associated with the causal and indicator variables are as expected and the most significant variables leading to the existence and development of the shadow economy are:

- Tax burden

- Regulatory burden

- Unemployment rate

- Self-employment rate

- Economic freedom index

\section{Results and Implications \\ MIMIC estimation result}

With reference to the MIMIC specification MIMIC 3 (4-1-2) in Table 1, we are able to estimate the size of the shadow economy from 1999 to 2013. The ranking of the size of the shadow economy of the 157 countries from smallest to largest is presented in Table $2^{6}$. The sizes of the shadow economy for the smaller sample based on MIMIC specification MIMIC 2 (5-1-2) are shown in Table 4. If we first consider the results of Table 3, we clearly see that Switzerland has an average shadow economy of 9.09\% (rank 1), followed by United States with

${ }^{6}$ We also used the estimations of MIMIC 5-1-3) from table 1 with the interaction term (tax burden) $x$ (economic freedom index) for calibration. We found only minor differences to the results in table 3 (without interaction term). For example the average of all 157 countries and the average over all years 1994 to 2013 is 33.82 in table 3 without the interaction term and 33.86 with the interaction term. Due to this single country results are not reported here. 
Citation: Hassan Mai, Schneider Friedrich (2016) Size and Development of the Shadow Economies of 157 Worldwide Countries: Updated and New Measures from 1999 to 2013. J Glob Econ 4: 218. doi: 10.4172/2375-4389.1000218

Page 6 of 14

\begin{tabular}{|c|c|c|c|c|c|c|c|c|c|c|c|c|c|c|c|c|c|}
\hline \multirow[t]{2}{*}{ No } & \multirow[t]{2}{*}{ Countryname } & \multicolumn{16}{|c|}{ Size of the shadow economy } \\
\hline & & 1999 & 2000 & 2001 & 2002 & 2003 & 2004 & 2005 & 2006 & 2007 & 2008 & 2009 & 2010 & 2011 & 2012 & 2013 & Averages \\
\hline 1 & Switzerland & 8.80 & 9.21 & 9.13 & 9.12 & 10.05 & 9.65 & 9.16 & 8.75 & 8.44 & 8.47 & 9.42 & 8.79 & 8.87 & 9.18 & 9.35 & 9.09 \\
\hline 2 & United States & 8.80 & 8.90 & 9.03 & 9.39 & 8.99 & 8.51 & 8.43 & 8.68 & 9.36 & 10.50 & 10.58 & 10.45 & 8.95 & 8.63 & 8.29 & 9.17 \\
\hline 3 & Austria & 10.00 & 9.28 & 10.03 & 9.97 & 9.99 & 9.90 & 9.67 & 9.31 & 9.23 & 9.83 & 10.11 & 10.05 & 9.75 & 10.18 & 10.13 & 9.83 \\
\hline 4 & Luxembourg & 10.00 & 9.37 & 10.00 & 10.91 & 11.33 & 11.23 & 11.56 & 10.20 & 10.26 & 10.38 & 11.16 & 10.85 & 10.63 & 11.63 & 13.47 & 10.87 \\
\hline 5 & Qatar & 18.70 & 15.67 & 15.56 & 13.97 & 13.34 & 12.87 & 12.62 & 12.22 & 10.99 & 8.97 & 12.18 & 10.24 & 9.77 & 10.06 & 10.45 & 12.51 \\
\hline 6 & Macao SAR, China & 13.30 & 12.30 & 12.82 & 12.6 & 12.73 & 11.50 & 11.38 & 10.84 & 12.36 & 14.03 & 14.29 & 14.51 & 14.50 & 14.72 & 12.64 & 12.97 \\
\hline 7 & Bahrain & 18.60 & 14.72 & 15.40 & 15.67 & 15.16 & 14.48 & 12.67 & 11.00 & 9.89 & 9.04 & 10.11 & 10.58 & 10.94 & 14.57 & 13.59 & 13.09 \\
\hline 8 & New Zealand & 13.00 & 12.35 & 12.23 & 12.24 & 12.37 & 12.45 & 13.10 & 13.96 & 13.85 & 15.24 & 14.93 & 14.32 & 13.91 & 13.76 & 13.13 & 13.39 \\
\hline 9 & Singapore & 13.30 & 14.13 & 15.64 & 15.41 & 14.31 & 12.49 & 12.01 & 12.39 & 12.45 & 14.16 & 13.46 & 13.35 & 11.95 & 12.61 & 13.44 & 13.41 \\
\hline 10 & China & 13.20 & 13.19 & 14.77 & 13.81 & 13.46 & 13.01 & 13.11 & 13.37 & 13.85 & 13.24 & 13.57 & 13.71 & 13.11 & 13.92 & 13.79 & 13.54 \\
\hline 11 & United Kingdom & 12.80 & 12.33 & 12.89 & 12.94 & 13.50 & 13.55 & 13.74 & 13.99 & 14.00 & 15.03 & 15.08 & 15.26 & 14.43 & 13.84 & 13.26 & 13.78 \\
\hline 12 & Japan & 11.40 & 11.72 & 12.59 & 13.61 & 12.92 & 13.52 & 12.87 & 12.65 & 13.89 & 14.56 & 15.53 & 15.34 & 15.44 & 15.50 & 15.56 & 13.81 \\
\hline 13 & Australia & 14.40 & 14.15 & 14.68 & 14.36 & 14.24 & 14.10 & 14.26 & 14.20 & 14.04 & 14.53 & 14.32 & 14.28 & 13.79 & 14.28 & 14.82 & 14.30 \\
\hline 14 & Kuwait & 20.10 & 16.12 & 18.21 & 19.78 & 17.31 & 15.98 & 11.52 & 9.87 & 10.60 & 10.13 & 15.09 & 14.26 & 13.13 & 13.00 & 12.58 & 14.51 \\
\hline 15 & Netherlands & 13.30 & 12.60 & 12.90 & 13.94 & 14.88 & 14.50 & 14.39 & 13.94 & 14.12 & 14.38 & 16.18 & 16.56 & 16.01 & 16.21 & 16.38 & 14.69 \\
\hline 16 & France & 15.70 & 14.32 & 14.44 & 15.09 & 15.63 & 15.41 & 15.77 & 15.17 & 14.79 & 15.10 & 16.37 & 14.86 & 14.43 & 14.98 & 15.03 & 15.14 \\
\hline 17 & Oman & 19.10 & 16.20 & 16.30 & 18.14 & 16.14 & 15.90 & 15.40 & 14.42 & 13.69 & 10.45 & 14.80 & 13.44 & 12.92 & 15.03 & 16.07 & 15.20 \\
\hline 18 & Germany & 16.40 & 15.74 & 15.27 & 16.57 & 17.40 & 16.78 & 16.45 & 14.31 & 13.94 & 14.66 & 16.27 & 15.65 & 15.18 & 15.91 & 15.96 & 15.77 \\
\hline 19 & Canada & 16.30 & 15.48 & 15.40 & 16.20 & 16.48 & 15.18 & 15.35 & 15.36 & 16.19 & 16.55 & 17.56 & 17.45 & 15.85 & 16.66 & 16.58 & 16.17 \\
\hline 20 & Iceland & 16.00 & 15.91 & 16.04 & 16.72 & 17.05 & 16.66 & 16.28 & 16.95 & 16.60 & 17.36 & 17.53 & 17.57 & 16.71 & 15.42 & 15.76 & 16.57 \\
\hline 21 & Ireland & 16.10 & 14.33 & 14.18 & 15.88 & 16.20 & 16.47 & 16.26 & 16.66 & 17.55 & 20.17 & 21.14 & 20.22 & 17.77 & 16.65 & 15.56 & 17.01 \\
\hline 22 & Vietnam & 15.80 & 14.87 & 14.55 & 14.49 & 14.53 & 15.60 & 14.39 & 14.65 & 16.21 & 15.98 & 16.37 & 22.80 & 21.41 & 21.78 & 24.14 & 17.17 \\
\hline 23 & Saudi Arabia & 18.70 & 19.13 & 21.48 & 19.17 & 19.33 & 18.08 & 15.82 & 16.68 & 15.99 & 13.19 & 16.55 & 16.16 & 15.23 & 16.52 & 17.73 & 17.32 \\
\hline 24 & Iran, Islamic Rep. & 19.10 & 20.85 & 20.02 & 16.99 & 12.45 & 17.17 & 16.04 & 21.89 & 14.54 & 16.81 & 21.12 & 20.10 & 16.94 & 16.84 & 16.71 & 17.84 \\
\hline 25 & Jordan & 19.40 & 21.76 & 20.44 & 19.43 & 17.91 & 18.01 & 17.94 & 20.04 & 18.34 & 17.52 & 17.38 & 16.60 & 17.06 & 17.58 & 6.14 & 18.37 \\
\hline 26 & Sweden & 19.60 & 17.87 & 17.86 & 18.13 & 19.45 & 19.33 & 19.25 & 18.43 & 18.26 & 18.54 & 19.90 & 18.84 & 18.53 & 18.65 & 18.95 & 18.77 \\
\hline 27 & Finland & 18.40 & 18.08 & 16.70 & 17.70 & 18.70 & 18.66 & 18.90 & 17.73 & 17.43 & 18.79 & 20.32 & 20.09 & 19.47 & 20.44 & 20.68 & 18.81 \\
\hline 28 & Czech Republic & 19.30 & 18.87 & 18.02 & 20.36 & 20.60 & 20.18 & 19.73 & 17.23 & 16.76 & 18.00 & 19.66 & 19.99 & 18.58 & 18.48 & 18.47 & 18.95 \\
\hline 29 & Denmark & 18.40 & 17.65 & 17.85 & 18.07 & 18.37 & 18.70 & 17.88 & 17.82 & 18.47 & 19.38 & 21.39 & 21.51 & 20.05 & 20.15 & 19.91 & 19.04 \\
\hline 30 & Chile & 19.90 & 18.22 & 18.54 & 18.21 & 19.19 & 17.75 & 18.26 & 18.25 & 20.05 & 21.15 & 20.34 & 20.59 & 19.19 & 19.81 & 19.74 & 19.28 \\
\hline 31 & Indonesia & 19.70 & 22.01 & 20.40 & 19.44 & 20.24 & 22.69 & 19.30 & 19.31 & 16.17 & 16.99 & 18.56 & 17.33 & 19.39 & 19.25 & 20.25 & 19.40 \\
\hline 32 & Norway & 19.20 & 19.06 & 20.57 & 21.22 & 21.05 & 20.83 & 19.80 & 18.23 & 18.69 & 18.99 & 20.56 & 20.99 & 20.43 & 20.52 & 19.92 & 20.01 \\
\hline 33 & $\begin{array}{l}\text { Hong Kong SAR, } \\
\text { China }\end{array}$ & 17.00 & 15.16 & 20.65 & 24.34 & 24.26 & 21.56 & 19.49 & 19.38 & 19.50 & 21.75 & 22.04 & 22.58 & 19.93 & 21.81 & 23.66 & 20.87 \\
\hline 34 & Israel & 22.70 & 23.01 & 23.33 & 24.00 & 23.90 & 21.63 & 20.65 & 20.28 & 20.04 & 19.94 & 19.39 & 19.80 & 19.56 & 19.82 & 20.45 & 21.23 \\
\hline 35 & Mongolia & 18.40 & 20.84 & 23.41 & 21.64 & 22.08 & 24.41 & 21.62 & 23.53 & 23.07 & 23.51 & 21.44 & 21.41 & 19.76 & 18.44 & 21.35 & 21.66 \\
\hline 36 & India & 23.20 & 23.77 & 21.47 & 20.71 & 21.54 & 21.20 & 20.67 & 22.18 & 21.04 & 21.72 & 22.43 & 22.22 & 20.71 & 22.25 & 21.24 & 21.76 \\
\hline 37 & Slovak Republic & 18.90 & 19.24 & 18.00 & 26.56 & 21.98 & 21.14 & 19.29 & 19.08 & 22.14 & 27.00 & 26.47 & 24.77 & 23.52 & 23.71 & 19.85 & \\
\hline 38 & Mauritius & 23.30 & 21.55 & 21.09 & 21.52 & 25.18 & 24.63 & 24.12 & 22.90 & 19.13 & 19.77 & 22.86 & 23.46 & 24.11 & 23.23 & 23.89 & 22.72 \\
\hline 39 & Belgium & 22.70 & 20.81 & 22.32 & 22.75 & 23.76 & 23.16 & 22.90 & 21.82 & 21.70 & 23.22 & 23.91 & 23.79 & 23.45 & 24.56 & 25.34 & 23.08 \\
\hline 40 & Eritrea & 38.10 & 32.53 & 27.57 & 26.33 & 29.20 & 25.11 & 24.53 & 20.74 & 20.65 & 20.89 & 18.38 & 19.84 & 18.17 & 12.74 & 12.78 & 23.17 \\
\hline 41 & Angola & 48.80 & 42.24 & 26.90 & 19.51 & 21.69 & 16.49 & 16.98 & 18.90 & 18.27 & 20.74 & 19.84 & 18.11 & 19.43 & 18.14 & 23.30 & 23.29 \\
\hline 42 & Maldives & 30.30 & 34.63 & 25.29 & 25.12 & 22.69 & 24.71 & 24.73 & 24.71 & 22.86 & 20.12 & 18.94 & 18.33 & 19.93 & 19.23 & 18.32 & 23.33 \\
\hline 43 & Spain & 23.00 & 18.87 & 19.60 & 20.59 & 22.54 & 21.47 & 22.17 & 21.57 & 24.99 & 28.85 & 30.40 & 30.86 & 28.59 & 27.62 & 28.11 & 24.61 \\
\hline 44 & Chad & 45.80 & 43.78 & 40.30 & 35.82 & 32.13 & 26.39 & 22.92 & 21.02 & 18.66 & 16.80 & 14.55 & 13.30 & 14.74 & 16.05 & 15.72 & 25.20 \\
\hline 45 & Portugal & 23.00 & 23.26 & 23.99 & 25.49 & 26.02 & 25.74 & 26.45 & 25.37 & 24.12 & 25.29 & 26.02 & 26.94 & 27.30 & 25.97 & 26.42 & 25.43 \\
\hline 46 & Hungary & 25.40 & 23.49 & 24.30 & 25.64 & 27.10 & 26.42 & 26.18 & 25.76 & 25.47 & 26.84 & 28.97 & 27.94 & 25.20 & 24.37 & 23.88 & 25.80 \\
\hline 47 & Botswana & 33.90 & 31.54 & 29.01 & 29.64 & 27.29 & 26.93 & 22.43 & 20.98 & 22.96 & 25.89 & 25.46 & 21.71 & 22.33 & 23.79 & 25.11 & 25.93 \\
\hline 48 & $\begin{array}{l}\text { United Arab } \\
\text { Emirates }\end{array}$ & 26.30 & 23.27 & 27.35 & 30.53 & 27.85 & 31.58 & 26.28 & 24.96 & 22.05 & 22.05 & 30.47 & 25.11 & 23.90 & 21.27 & 28.41 & 26.09 \\
\hline 49 & Argentina & 25.20 & 27.84 & 29.29 & 26.10 & 24.51 & 17.96 & 19.73 & 20.06 & 22.00 & 24.08 & 27.64 & 28.06 & 28.85 & 35.08 & 36.10 & 26.17 \\
\hline 50 & Latvia & 30.80 & 28.53 & 26.71 & 26.11 & 26.20 & 23.95 & 23.59 & 22.64 & 24.35 & 33.94 & 34.75 & 31.07 & 24.29 & 20.96 & 19.92 & 26.52 \\
\hline 51 & Bahamas, The & 26.30 & 25.73 & 26.68 & 27.80 & 27.62 & 26.26 & 22.69 & 22.85 & 22.78 & 28.41 & 30.70 & 31.71 & 25.99 & 26.03 & 29.11 & 26.71 \\
\hline 52 & Malta & 27.40 & 27.16 & 28.48 & 31.03 & 30.70 & 31.70 & 30.06 & 32.53 & 32.46 & 21.83 & 22.42 & 21.84 & 21.29 & 21.50 & 21.62 & 26.80 \\
\hline 53 & Poland & 27.70 & 32.78 & 31.20 & 28.80 & 29.42 & 26.36 & 23.37 & 22.00 & 21.46 & 24.18 & 27.49 & 28.48 & 27.76 & 26.87 & 26.62 & 26.97 \\
\hline 54 & Equatorial Guinea & 32.70 & 23.65 & 18.18 & 28.51 & 17.76 & 20.32 & 17.35 & 20.67 & 18.26 & 19.85 & 35.16 & 38.12 & 37.43 & 40.84 & 42.48 & 27.42 \\
\hline
\end{tabular}


Page 7 of 14

\begin{tabular}{|c|c|c|c|c|c|c|c|c|c|c|c|c|c|c|c|c|c|}
\hline 50 & Slovenia & 27.30 & 26.95 & 25.96 & 27.70 & 28.00 & 27.03 & 26.90 & 25.86 & 25.16 & 26.28 & 28.14 & 29.01 & 29.48 & 29.97 & 29.49 & 27.55 \\
\hline 56 & Estonia & 33.00 & 33.14 & 23.17 & 24.70 & 24.96 & 25.41 & 22.48 & 19.69 & 21.08 & 35.64 & 43.86 & 37.82 & 24.96 & 21.70 & 22.94 & 27.64 \\
\hline 57 & Italy & 27.80 & 25.55 & 26.00 & 26.35 & 26.73 & 27.03 & 26.75 & 28.47 & 27.48 & 29.16 & 31.58 & 30.22 & 31.22 & 32.02 & 32.01 & 28.56 \\
\hline 58 & Lithuania & 33.80 & 35.38 & 28.75 & 28.93 & 25.07 & 25.49 & 24.79 & 24.87 & 26.41 & 34.52 & 39.13 & 34.36 & 26.00 & 21.85 & 21.95 & 28.75 \\
\hline 59 & Croatia & 33.80 & 36.71 & 30.34 & 27.09 & 23.01 & 25.92 & 25.91 & 24.26 & 25.48 & 26.06 & 29.83 & 30.34 & 31.66 & 32.10 & 31.61 & 28.94 \\
\hline 60 & Namibia & 31.40 & 30.74 & 28.98 & 26.79 & 26.71 & 27.79 & 27.37 & 26.17 & 32.72 & 33.92 & 31.99 & 25.77 & 21.42 & 30.25 & 33.54 & 29.04 \\
\hline 61 & South Africa & 28.40 & 28.49 & 29.29 & 28.43 & 27.10 & 27.37 & 28.48 & 27.88 & 28.73 & 30.38 & 31.00 & 31.58 & 30.71 & 30.06 & 30.62 & 29.23 \\
\hline 62 & Yemen, Rep. & 27.70 & 27.68 & 26.91 & 23.79 & 24.82 & 25.22 & 22.63 & 26.27 & 25.16 & 27.87 & 31.34 & 36.13 & 37.68 & 37.02 & 38.92 & 29.28 \\
\hline 63 & Guinea-Bissau & 40.40 & 46.21 & 37.24 & 37.30 & 36.89 & 32.24 & 29.03 & 27.52 & 26.09 & 20.47 & 21.19 & 24.70 & 21.46 & 20.70 & 18.00 & 29.30 \\
\hline 64 & Kenya & 33.70 & 32.53 & 34.89 & 35.71 & 33.56 & 29.04 & 31.12 & 24.86 & 25.97 & 27.73 & 27.06 & 26.07 & 25.58 & 25.32 & 26.37 & 29.30 \\
\hline 65 & Colon & 39.40 & 32.45 & 29.91 & 27.95 & 28.15 & 27.28 & 28.06 & 26.30 & 28.76 & 28.45 & 31.30 & 29.36 & 29.16 & 29.18 & 29.85 & 29.70 \\
\hline 66 & Fiji & 32.90 & 32.55 & 33.61 & 32.24 & 30.66 & 28.27 & 28.84 & 36.39 & 34.93 & 32.31 & 28.23 & 26.99 & 24.71 & 26.26 & 25.52 & 30.29 \\
\hline 67 & Suriname & 39.70 & 40.48 & 34.45 & 27.86 & 30.66 & 28.15 & 24.95 & 25.11 & 30.04 & 32.07 & 30.52 & 29.36 & 27.52 & 33.37 & 30.44 & 30.98 \\
\hline 68 & $\begin{array}{l}\text { Trinidad } \\
\text { Tobago }\end{array}$ & 34.70 & 6.77 & 30.39 & 29.63 & 28.16 & 25.58 & 28.25 & 31.63 & 27.43 & 30.16 & 6.13 & 35.61 & 32.74 & 33.80 & 34.10 & 31.01 \\
\hline 69 & Mexico & 30.80 & 31.05 & 31.34 & 30.82 & 31.47 & 30.49 & 30.92 & 29.79 & 29.13 & 32.72 & 35.07 & 31.97 & 30.42 & 32.91 & 31.51 & 31.36 \\
\hline 70 & Togo & 34.40 & 35.38 & 33.14 & 28.70 & 29.85 & 29.44 & 29.81 & 31.55 & 27.19 & 29.35 & 31.03 & 28.55 & 28.25 & 34.86 & 39.14 & 31.38 \\
\hline 71 & Costa Rica & 26.10 & 26.14 & 30.17 & 31.62 & 30.53 & 29.89 & 28.74 & 27.57 & 28.91 & 32.97 & 34.87 & 37.16 & 34.44 & 35.45 & 36.73 & 31.42 \\
\hline 72 & Pakistan & 37.00 & 30.74 & 30.47 & 31.11 & 31.52 & 28.27 & 26.59 & 26.25 & 29.41 & 31.63 & 31.87 & 34.87 & 31.31 & 34.28 & 36.05 & 31.43 \\
\hline 73 & Central Af & 42.80 & 1.91 & 37.15 & 37.32 & 29.81 & 32.46 & 31.68 & 25.17 & 25.66 & 26.67 & 26.33 & 28.60 & 26.71 & 27.32 & 34.66 & 31.62 \\
\hline 74 & Lebanon & 34.10 & 34.82 & 31.45 & 36.49 & 34.98 & 32.92 & 31.98 & 32.89 & 28.66 & 29.67 & 29.32 & 28.50 & 29.43 & 28.33 & 32.16 & 31.71 \\
\hline 75 & Cyprus & 29.20 & 28.64 & 27.77 & 29.61 & 33.11 & 33.18 & 34.26 & 34.35 & 36.42 & 37.26 & 29.34 & 29.75 & 30.59 & 32.64 & 33.79 & 31.99 \\
\hline 76 & Korea, R & 28.30 & 25.57 & 27.84 & 29.15 & 31.36 & 31.66 & 32.64 & 32.30 & 33.81 & 35.12 & 36.24 & 33.49 & 34.36 & 34.15 & 34.77 & 32.05 \\
\hline 77 & Greece & 28.50 & 28.11 & 27.61 & 30.02 & 28.80 & 28.17 & 29.46 & 28.47 & 29.85 & 30.65 & 35.72 & 37.62 & 42.34 & 43.67 & 39.39 & 32.56 \\
\hline 78 & Algeria & 34.20 & 39.30 & 34.84 & 30.87 & 28.47 & 24.58 & 25.66 & 30.22 & 30.05 & 36.89 & 35.21 & 37.79 & 46.42 & 29.80 & 27.24 & 32.77 \\
\hline 79 & Romania & 34.30 & 35.30 & 35.01 & 31.56 & 37.12 & 32.61 & 33.98 & 30.16 & 30.80 & 33.13 & 35.29 & 33.50 & 31.90 & 32.13 & 30.65 & 33.16 \\
\hline 80 & Venezuela, RB & 33.80 & 29.92 & 39.16 & 36.64 & 35.39 & 32.03 & 26.08 & 26.68 & 29.03 & 34.72 & 50.10 & 37.89 & 32.50 & 32.98 & 31.64 & 33.91 \\
\hline 81 & Lesotho & 31.70 & 33.62 & 32.26 & 36.12 & 31.78 & 35.11 & 31.36 & 34.04 & 32.94 & 30.65 & 32.59 & 39.05 & 37.53 & 36.51 & 33.35 & 33.91 \\
\hline 82 & Macedoni & 39.00 & 31.68 & 41.52 & 41.19 & 39.25 & 39.33 & 31.84 & 29.32 & 30.06 & 32.12 & 32.75 & 30.21 & 32.66 & 30.73 & 29.93 & 34.11 \\
\hline 83 & Serbia & 34.30 & 33.04 & 35.59 & 39.17 & 41.52 & 39.07 & 36.53 & 32.19 & 28.51 & 29.44 & 31.58 & 37.35 & 34.74 & 32.42 & 27.95 & 34.23 \\
\hline 84 & Bhutan & 29.60 & 37.77 & 35.99 & 34.91 & 35.10 & 35.09 & 37.03 & 36.49 & 32.15 & 32.68 & 35.48 & 32.44 & 31.75 & 33.04 & 34.60 & 34.28 \\
\hline 85 & Bulgaria & 36.00 & 42.52 & 37.56 & 31.63 & 31.86 & 31.65 & 32.49 & 33.15 & 33.11 & 34.42 & 35.97 & 37.30 & 33.99 & 33.59 & 35.55 & 34.72 \\
\hline 86 & Cameroon & 33.30 & 31.70 & 32.63 & 31.81 & 30.70 & 32.03 & 30.98 & 30.49 & 33.39 & 34.44 & 44.69 & 37.62 & 45.22 & 37.43 & 37.40 & 34.92 \\
\hline 87 & Papua New G & 35.50 & 33.53 & 35.84 & 32.90 & 33.28 & 33.60 & 34.09 & 34.27 & 34.75 & 35.16 & 35.58 & 38.71 & 37.27 & 33.89 & 35.84 & 34.95 \\
\hline 88 & Montenegro & 34.30 & 36.79 & 40.18 & 40.34 & 39.93 & 37.57 & 39.72 & 38.20 & 31.00 & 33.70 & 32.52 & 31.82 & 33.50 & 31.35 & 28.75 & 35.31 \\
\hline 89 & Malaysia & 32.20 & 31.65 & 40.70 & 39.41 & 36.45 & 36.72 & 32.27 & 32.75 & 31.98 & 34.00 & 36.49 & 34.08 & 35.34 & 38.41 & 37.35 & 35.32 \\
\hline 90 & Cabo Verde & 36.50 & 37.30 & 37.15 & 36.96 & 36.39 & 39.01 & 38.70 & 39.83 & 36.84 & 36.06 & 35.66 & 39.02 & 37.11 & 22.44 & 20.98 & 35.33 \\
\hline 91 & $\begin{array}{l}\text { Bosnia and } \\
\text { Herzegovina }\end{array}$ & 34.30 & 0.24 & 38.06 & 36.87 & 36.69 & 36.99 & 38.82 & 34.96 & 34.71 & 32.37 & 36.08 & 37.13 & 39.44 & 38.41 & 36.45 & 36.10 \\
\hline 92 & Ecuador & 34.20 & 35.05 & 36.27 & 34.72 & 29.81 & 29.89 & 30.44 & 29.63 & 32.96 & 36.98 & 45.16 & 43.80 & 42.49 & 45.57 & 47.21 & 36.94 \\
\hline 93 & Morocco & 36.50 & 35.77 & 34.89 & 36.96 & 35.12 & 36.79 & 39.11 & 37.76 & 34.76 & 38.34 & 37.10 & 36.57 & 38.76 & 40.69 & 40.72 & 37.32 \\
\hline 94 & Turkey & 32.70 & 29.51 & 38.50 & 43.00 & 38.64 & 34.65 & 36.08 & 32.63 & 38.26 & 41.27 & 43.30 & 40.56 & 36.70 & 41.38 & 32.70 & 37.33 \\
\hline 95 & Egypt, Arab & 35.50 & 41.03 & 37.40 & 37.31 & 38.15 & 39.02 & 38.22 & 38.43 & 32.97 & 31.85 & 37.37 & 38.39 & 39.39 & 39.53 & 39.35 & 37.59 \\
\hline 96 & Philippines & 43.80 & 45.74 & 44.43 & 38.38 & 38.51 & 31.70 & 34.05 & 29.63 & 36.81 & 35.45 & 36.31 & 36.56 & 36.20 & 39.15 & 38.72 & 37.69 \\
\hline 97 & Malawi & 39.90 & 39.48 & 42.04 & 37.51 & 36.72 & 34.41 & 36.09 & 34.58 & 33.76 & 36.20 & 39.34 & 35.59 & 41.01 & 40.58 & 44.07 & 38.09 \\
\hline 98 & $\begin{array}{l}\text { Dominican } \\
\text { Republic }\end{array}$ & 32.40 & 37.39 & 41.48 & 42.65 & 37.28 & 36.75 & 33.79 & 31.17 & 35.27 & 39.60 & 36.02 & 39.40 & 38.43 & 46.14 & 43.54 & 38.09 \\
\hline 99 & Timor-Leste & 35.50 & 0.99 & 41.35 & 39.72 & 36.60 & 35.40 & 33.70 & 35.44 & 35.09 & 33.52 & 39.89 & 41.35 & 42.44 & 41.62 & 2.20 & 38.32 \\
\hline 100 & Rwanda & 40.50 & 34.47 & 41.50 & 36.12 & 38.95 & 30.05 & 46.90 & 44.94 & 41.61 & 36.07 & 37.42 & 35.73 & 34.87 & 37.50 & 38.55 & 38.35 \\
\hline 101 & Bangladesh & 36.00 & 38.69 & 33.14 & 38.10 & 43.97 & 39.27 & 41.25 & 31.10 & 47.17 & 44.73 & 34.46 & 34.45 & 37.12 & 40.31 & 42.61 & 38.83 \\
\hline 102 & Swaziland & 43.50 & 42.35 & 40.46 & 40.13 & 37.80 & 37.65 & 37.70 & 35.25 & 36.51 & 35.10 & 40.69 & 46.54 & 41.29 & 43.17 & 36.33 & 39.63 \\
\hline 103 & Tunisia & 38.70 & 38.24 & 39.10 & 39.65 & 39.73 & 38.21 & 39.10 & 36.56 & 36.07 & 40.25 & 40.89 & 44.50 & 43.60 & 43.64 & 39.45 & 39.85 \\
\hline 104 & Guyana & 33.40 & 41.38 & 42.77 & 44.01 & 48.78 & 46.45 & 45.23 & 37.67 & 37.03 & 41.29 & 40.05 & 40.26 & 31.94 & 33.65 & 34.30 & 39.88 \\
\hline 105 & Zambia & 49.30 & 50.33 & 49.21 & 46.00 & 44.88 & 42.73 & 40.42 & 37.60 & 37.05 & 35.37 & 32.20 & 31.66 & 34.02 & 33.19 & 36.65 & 40.04 \\
\hline 106 & Mauritania & 35.50 & 36.39 & 36.40 & 44.00 & 46.87 & 45.23 & 45.29 & 40.60 & 45.06 & 39.51 & 40.39 & 39.14 & 33.12 & 36.79 & 39.04 & 40.22 \\
\hline 107 & Jamaica & 36.40 & 36.31 & 36.25 & 35.60 & 33.45 & 34.72 & 37.75 & 38.37 & 42.16 & 45.72 & 47.55 & 45.30 & 44.45 & 46.72 & 45.17 & 40.40 \\
\hline 108 & Brazil & 40.80 & 39.40 & 40.31 & 43.15 & 39.97 & 41.56 & 40.88 & 41.55 & 41.72 & 41.00 & 41.08 & 40.54 & 38.02 & 37.52 & 41.18 & 40.58 \\
\hline 109 & Paraguay & 38.00 & 43.28 & 48.36 & 37.37 & 36.80 & 29.03 & 39.02 & 35.26 & 35.44 & 36.19 & 43.92 & 41.47 & 41.51 & 49.98 & 53.73 & 40.62 \\
\hline 110 & Barbados & 33.80 & 32.24 & 34.62 & 37.72 & 45.13 & 41.94 & 39.16 & 34.54 & 42.23 & 45.03 & 47.12 & 48.22 & 49.26 & 41.05 & 39.94 & 40.80 \\
\hline
\end{tabular}




\begin{tabular}{|c|c|c|c|c|c|c|c|c|c|c|c|c|c|c|c|c|c|}
\hline 111 & iger & 41.70 & 7.47 & 32.69 & 35.10 & 38.05 & 43.69 & 43.05 & 42.83 & 42.86 & 42.47 & 44.51 & 44.74 & 40.83 & 41.46 & 41.20 & 40.84 \\
\hline 112 & ote d'Ivoire & 41.40 & 3.70 & 38.68 & 39.03 & 43.45 & 3.37 & 3.57 & 2.12 & 42.57 & 1.02 & 39.20 & 39.26 & 2.67 & 4.36 & 1.04 & 41.03 \\
\hline 113 & pal & 37.20 & 3.23 & 36.62 & 4.57 & 34.92 & 6.71 & 8.50 & 5.45 & 9.90 & 3.69 & 8.71 & 7.56 & 8.06 & 9.87 & 9.38 & 41.62 \\
\hline T & yrgyz F & 41.40 & 1.00 & 44.15 & 44.44 & 36.43 & 35.90 & 39.19 & 38.58 & 41.91 & 41.82 & 42.56 & 42.57 & 43.16 & 47.93 & 4.82 & 41.72 \\
\hline 115 & Ibania & 35.70 & 7.77 & 32.64 & 39.03 & 40.10 & 39.04 & 12.15 & 1.06 & 2.58 & 45.28 & 46.97 & 47.21 & 9.51 & 0.78 & 1.96 & 2.12 \\
\hline 116 & adagascar & 40.10 & 4.33 & 44.85 & 36.95 & 36.07 & 34.95 & 38.02 & 44.58 & 56.10 & 46.81 & 41.02 & 43.65 & 44.69 & 42.70 & 4.82 & 42.64 \\
\hline 117 & ussian Fede & 36.00 & 3.71 & 38.92 & 42.19 & 41.34 & 40.05 & 44.45 & 43.14 & 44.65 & 48.46 & 49.51 & 45.64 & 42.38 & 4.94 & 6.37 & 42.78 \\
\hline 110 & omoros & 39.30 & 35.82 & 42.84 & 42.54 & 38.75 & 37.56 & 37.47 & 38.92 & 3.61 & 5.65 & 7.44 & 6.86 & 1.01 & 2.96 & 0.11 & 2.79 \\
\hline 119 & Mozambiq & 36.00 & 31.76 & 35.03 & 36.02 & 36.82 & 41.49 & 42.35 & 42.28 & 39.67 & 42.68 & 46.56 & 48.10 & 50.56 & 53.54 & 3.09 & 43.06 \\
\hline 120 & ganda & 43.50 & 50.51 & 48.16 & 52.61 & 50.92 & 40.01 & 49.16 & 47.32 & 47.49 & 41.59 & 36.22 & 36.24 & 45.79 & 31.76 & 2.80 & 43.61 \\
\hline 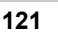 & ana & 42.00 & 0.96 & 39.82 & 38.30 & 40.75 & 41.90 & 52.85 & 34.12 & 39.97 & 38.55 & 39.74 & 36.44 & 55.49 & 1.09 & 7.01 & 43.93 \\
\hline 政 & ali & 42.50 & 0.63 & 40.51 & 42.95 & 48.71 & 48.26 & 44.55 & 47.32 & 45.49 & 44.49 & 45.22 & 45.13 & 44.85 & 44.82 & 46.61 & 44.80 \\
\hline 120 & olomon Isla & 31.70 & 35.08 & 34.57 & 31.09 & 30.23 & 36.63 & 43.26 & 45.88 & 48.50 & 51.18 & 53.54 & 57.13 & 57.02 & 60.57 & 6.23 & 45.51 \\
\hline 124 & ongo, Rep. & 49.50 & 41.58 & 45.61 & 58.27 & 54.62 & 50.68 & 41.71 & 45.97 & 52.55 & 38.11 & 42.61 & 38.92 & 34.74 & 46.14 & 42.47 & 45.57 \\
\hline 125 & rmenia & 46.60 & 48.25 & 56.59 & 55.03 & 53.63 & 39.92 & 43.99 & 37.28 & 35.12 & 30.62 & 41.99 & 50.74 & 50.54 & 44.82 & 48.47 & 45.57 \\
\hline 126 & azakhst & 43.80 & 9.50 & 43.33 & 42.67 & 47.04 & 52.78 & 37.52 & 35.83 & 42.97 & 42.60 & 49.84 & 7.37 & 0.91 & 6.58 & 5.69 & 45.90 \\
\hline 127 & elarus & 48.30 & 5.01 & 3.02 & 48.35 & 52.08 & 49.61 & 51.44 & 51.84 & 52.62 & 51.03 & 45.71 & 41.66 & 7.35 & 6.71 & 7.67 & 46.83 \\
\hline 120 & eorgia & 34.00 & 6.65 & 2.46 & 28.76 & 20.00 & 38.91 & 49.97 & 41.84 & 61.11 & 78.74 & 74.47 & 61.46 & 57.13 & 57.27 & 3.20 & 46.85 \\
\hline 2 & zerbaija & 61.00 & 2.81 & 51.10 & 36.29 & 42.10 & 46.32 & 4.41 & 49.68 & 46.34 & 43.94 & 46.76 & 45.43 & 43.32 & 46.23 & 6.54 & 47.48 \\
\hline 130 & Burundi & 39.10 & 33.56 & 35.27 & 34.42 & 39.16 & 42.37 & 42.32 & 43.99 & 58.79 & 62.07 & 57.54 & 64.44 & 56.88 & 52.74 & 49.74 & 47.49 \\
\hline 131 & Suinea & 39.70 & 0.97 & 41.11 & 49.96 & 43.21 & 39.52 & 40.13 & 49.89 & 39.53 & 48.80 & 50.24 & 67.98 & 57.10 & 56.29 & 53.60 & 47.87 \\
\hline 132 & i Lan & 45.20 & 5.66 & .53 & 56.06 & 52.93 & 2.08 & 52.45 & 60.20 & 56.72 & 62.60 & 66.31 & 52.49 & 6.45 & 27.62 & 8.44 & 48.72 \\
\hline 133 & ambodia & 50.40 & .71 & .75 & 3.72 & .21 & 66 & 7 & 84 & .85 & .75 & 06 & 1 & 3 & 26 & 18 & 49.21 \\
\hline . & urk & 41.00 & 7.00 & 6.34 & 46.58 & 46.28 & 9.02 & 6.44 & 0.72 & 5.47 & 9.92 & 48.10 & 48.68 & 48.72 & 1.53 & 0 & 49.25 \\
\hline $10=$ & Cal & 45.70 & 7.92 & 46.53 & 45.30 & 0.63 & 2.29 & 8.75 & 49.25 & 1.28 & 53.19 & 54.25 & 3.97 & 49.09 & 4.49 & 0.49 & 49.27 \\
\hline 130 & igeria & 46.00 & 6.21 & 55.41 & 37.84 & 32.86 & 37.08 & 43.47 & 40.52 & 51.28 & 74.29 & 79.42 & 47.77 & 48.03 & 46.42 & 42.94 & 49.30 \\
\hline 137 & Senegal & 45.00 & 48.59 & 40.08 & 43.77 & 45.28 & 51.10 & 49.52 & 49.07 & 48.86 & 48.43 & 52.87 & 55.27 & 52.45 & 57.01 & 52.58 & 49.33 \\
\hline 138 & Congo, D & 4.00 & 9.82 & 21.76 & 34.32 & 29.71 & 38.23 & 2.75 & 56.04 & 89 & 51.87 & 53 & 60.72 & 85 & 78.47 & 20 & 50.01 \\
\hline 139 & Lao PDR & 30.90 & 31.19 & 39.01 & 2417 & 35.83 & 40.23 & 44.18 & 45.66 & 50.79 & 58.83 & 8 & 59.73 & 5 & 74.05 & 80.41 & .19 \\
\hline 140 & EI Salvador & 46.50 & 5.37 & 51.45 & 47.40 & 48.12 & 48.06 & 47.16 & 51.14 & 47.80 & 10 & 51.62 & 54.26 & 52.77 & 54.12 & 58.60 & 50.37 \\
\hline 141 & Belize & 45.20 & 7.07 & 40.53 & 48.20 & 51.11 & 50.08 & 48.85 & 48.37 & 51.32 & 55.78 & 58.05 & 62.45 & 56.81 & 55.80 & 2.81 & 50.83 \\
\hline 14 & J|K| & 43.50 & 4.28 & 38.50 & 40.55 & 41.53 & 48.47 & 60.72 & 51.83 & 48.49 & 52.96 & 63.57 & 64.12 & 9.77 & 53.03 & 3.76 & 51.67 \\
\hline 143 & kraine & 52.70 & 2.57 & 48.52 & 47.09 & 47.09 & 4.92 & 50.23 & 52.76 & 53.88 & 52.77 & 60.07 & 59.49 & 53.60 & 54.24 & 3.53 & 52.23 \\
\hline 144 & ierra Lec & 48.60 & 2.06 & 56.55 & 61.02 & 54.49 & 8.09 & 7.31 & 49.27 & 43.62 & 48.42 & 54.14 & 52.95 & 1.53 & 2.80 & 54.74 & 52.37 \\
\hline & ruguay & 50.50 & 50.81 & 48.34 & 40.00 & 40.21 & . & 55.01 & 5 & 0 & 5 & 8 & 53.62 & 4 & 0 & & 52.38 \\
\hline 140 & . & 46.20 & 2.21 & .74 & 56.87 & 3.12 & .81 & .01 & 49.83 & .02 & 49.00 & 56.03 & 50.32 & 45.69 & 57.82 & 13 & 52.47 \\
\hline 147 & Haiti & 54.80 & 58.21 & 58.29 & 60.49 & 54.23 & 48.56 & 54.43 & 55.38 & 51.32 & 52.53 & 48.41 & 44.97 & 46.75 & 50.87 & 54.73 & 52.93 \\
\hline 148 & Moldova & 36.00 & 5.40 & 40.49 & 51.57 & 53.85 & 49.79 & 49.41 & 58.98 & 55.58 & 62.37 & 72.20 & 70.66 & 61.45 & 62.37 & 55.80 & 53.73 \\
\hline 149 & iberia & 44.20 & 43.57 & 41.16 & 31.39 & 33.50 & 54.90 & 54.60 & 51.91 & 62.21 & 76.93 & 64.90 & 67.76 & 70.76 & 76.84 & 2.04 & 57.11 \\
\hline 150 & hailand & 53.40 & 2.18 & 9.50 & .46 & .73 & 66 & 7 & 64 & 97 & 21 & 67 & 49 & 07 & 68 & 0 & .64 \\
\hline 151 & eru & 60.10 & 7.33 & 57.88 & 61.68 & 59.73 & 3.15 & 1.91 & 61.23 & 57.28 & 91 & 59.49 & 55.47 & .06 & 62.23 & .90 & 59.36 \\
\hline 152 & & 51.20 & 50.55 & 53.65 & 55.12 & 59.64 & 58.05 & 59.24 & 58.42 & 60.49 & 65.63 & 67.85 & 68.71 & 65.74 & 67.39 & 66.52 & 60.55 \\
\hline 153 & Gambia, $T$ & 46.10 & 52.83 & 52.57 & 52.82 & 54.57 & 54.68 & 51.35 & 52.19 & 59.54 & 74.62 & 81.35 & 79.77 & 78.65 & 64.30 & 64.80 & 61.34 \\
\hline 154 & Tanzania & 58.60 & 63.70 & 57.32 & 55.30 & 65.01 & 66.60 & 76.27 & 69.43 & 76.46 & 63.86 & 70.58 & 65.35 & 65.93 & 66.78 & 68.24 & 65.96 \\
\hline 155 & Guatemala & 51.60 & 53.98 & 69.76 & 78.31 & 74.69 & 70.03 & 1.02 & 63. & 65.42 & 71.00 & 73.33 & 72.35 & 3.53 & 70.86 & 70.82 & 67.68 \\
\hline 156 & Honduras & 50.30 & 57.28 & 63.34 & 00.02 & ט. & 72.43 & 64.83 & 60.49 & 71.07 & 76.41 & 81.45 & 78.60 & 71.67 & 69.22 & 72.41 & 68.17 \\
\hline \multirow[t]{2}{*}{157} & Bolivia & 67.00 & 72.33 & 71.70 & 76.91 & 73.86 & 73.83 & 78.62 & 70.98 & 67.20 & 64.20 & 75.55 & 81.20 & 76.92 & 68.17 & 66.04 & 72.30 \\
\hline & Time Average & 33.02 & 2.56 & 33.04 & 33.22 & 33.01 & 32.63 & 32.67 & 32.18 & 33.00 & 34.41 & 36.28 & 35.71 & 34.90 & 35.21 & 35.45 & 33.82 \\
\hline
\end{tabular}

Table 3: Ranking of 157 countries according to the size of the shadow economy.

9.2\%, followed by Austria with 9.8\% and Bolivia has the largest shadow economy with an average value of $72.19 \%$, followed by Honduras by with $86.2 \%$ and Guatemala with $67.87 \%$.

If we consider Table 4, the sample shrinks to 117 countries but here we included the causal variable "self-employment". Singapore has the lowest ranking with an average value of $7.24 \%$, followed by Switzerland with $9.03 \%$ and the United States with $9.35 \%$. Bolivia has the highest one with $69.9 \%$, followed by Honduras with $68.74 \%$ and Tanzania with
$66.73 \%$. We are aware that the size and development of the shadow economy is quite high for some countries, but we would argue that for developing countries we estimate a parallel economy, which we will discuss in 4.2. Of course, in order to undertake a detailed investigation about the size of the shadow economy a country by country study should be undertaken. One should be aware that when estimating so many countries in one sample, it is not possible to take into consideration the distinct differences in the institutions and economic development of all of the countries. 
Citation: Hassan Mai, Schneider Friedrich (2016) Size and Development of the Shadow Economies of 157 Worldwide Countries: Updated and New Measures from 1999 to 2013. J Glob Econ 4: 218. doi: 10.4172/2375-4389.1000218

Page 9 of 14

\begin{tabular}{|c|c|c|c|c|c|c|c|c|c|c|c|c|c|c|c|c|c|}
\hline \multirow[t]{2}{*}{ No. } & \multirow[t]{2}{*}{ Countryname } & \multicolumn{16}{|c|}{ Size of the shadow economy } \\
\hline & & 1999 & 2000 & 2001 & 2002 & 2003 & 2004 & 2005 & 2006 & 2007 & 2008 & 2009 & 2010 & 2011 & 2012 & 2013 & Averages \\
\hline 1 & Switzerland & 8.80 & 8.96 & 9.02 & 9.23 & 10.05 & 9.65 & 9.01 & 8.67 & 8.33 & 8.33 & 9.31 & 8.74 & 8.82 & 9.14 & 9.31 & 9.03 \\
\hline 2 & United States & 8.80 & 8.84 & 9.12 & 9.63 & 9.26 & 8.76 & 8.56 & 8.76 & 9.46 & 10.83 & 11.08 & 10.84 & 9.19 & 8.78 & 8.37 & 9.35 \\
\hline 3 & Austria & 10.00 & 9.27 & 9.93 & 9.89 & 9.93 & 9.86 & 9.71 & 9.41 & 9.21 & 9.85 & 10.22 & 10.14 & 9.77 & 10.18 & 10.19 & 9.84 \\
\hline 4 & Luxembourg & 10.00 & 9.21 & 9.99 & 10.93 & 11.61 & 11.43 & 11.65 & 10.13 & 10.17 & 10.46 & 11.36 & 11.07 & 10.75 & 11.80 & 13.11 & 10.91 \\
\hline 5 & $\begin{array}{l}\text { Macao SAR, } \\
\text { China }\end{array}$ & 13.30 & 12.12 & 12.54 & 12.21 & 12.13 & 10.49 & 10.27 & 9.51 & 10.70 & 12.15 & 12.63 & 12.40 & 11.93 & 12.12 & 10.47 & 11.67 \\
\hline 6 & Bahrain & 18.60 & 14.77 & 15.41 & 15.75 & 15.32 & 14.33 & 12.78 & 11.24 & 10.09 & 9.24 & 10.50 & 10.91 & 11.32 & 14.41 & 13.58 & 13.22 \\
\hline 7 & New Zealand & 13.00 & 12.14 & 12.05 & 12.10 & 12.24 & 12.31 & 12.96 & 13.77 & 13.84 & 15.35 & 15.13 & 14.66 & 14.23 & 13.90 & 13.18 & 13.39 \\
\hline 8 & Japan & 11.40 & 11.59 & 12.44 & 13.38 & 12.73 & 13.20 & 12.54 & 12.29 & 13.36 & 14.08 & 15.07 & 14.83 & 14.92 & 14.98 & 15.04 & 13.46 \\
\hline 9 & Singapore & 13.3 & 14.3 & 16 & 16 & 14.9 & 12.9 & 12.3 & 12.6 & 12.6 & 14.4 & 13.6 & 13.6 & 12.1 & 12.7 & 13.5 & 13.65 \\
\hline 10 & United Kingdom & 12.80 & 12.24 & 12.91 & 13.14 & 13.81 & 13.88 & 14.09 & 14.31 & 14.30 & 15.40 & 15.74 & 15.83 & 14.84 & 14.23 & 13.59 & 14.07 \\
\hline 11 & Australia & 14.40 & 13.99 & 14.44 & 14.19 & 14.00 & 13.82 & 13.97 & 13.89 & 13.78 & 14.34 & 14.34 & 14.42 & 13.82 & 14.30 & 14.80 & 14.17 \\
\hline 12 & Netherlands & 13.30 & 12.54 & 12.95 & 14.11 & 15.17 & 14.78 & 14.57 & 14.17 & 14.27 & 14.67 & 16.74 & 17.08 & 16.58 & 16.80 & 17.05 & 14.98 \\
\hline 13 & France & 15.70 & 13.99 & 14.24 & 15.13 & 15.80 & 15.58 & 15.88 & 15.22 & 14.83 & 15.22 & 16.71 & 15.65 & 15.16 & 15.62 & 15.66 & 15.36 \\
\hline 14 & Vietnam & 15.80 & 13.83 & 13.71 & 13.48 & 13.31 & 12.32 & 11.32 & 12.19 & 15.52 & 15.29 & 15.67 & 20.49 & 19.04 & 19.57 & 21.73 & 15.55 \\
\hline 15 & Germany & 16.40 & 15.72 & 15.46 & 16.74 & 17.58 & 17.03 & 16.55 & 14.36 & 13.73 & 14.50 & 16.23 & 15.69 & 15.15 & 15.80 & 15.93 & 15.79 \\
\hline 16 & Canada & 16.30 & 15.25 & 15.43 & 16.32 & 16.58 & 15.29 & 15.37 & 15.47 & 16.25 & 16.93 & 18.15 & 17.94 & 16.28 & 17.00 & 16.98 & 16.37 \\
\hline 17 & Iceland & 16.00 & 15.94 & 16.23 & 16.77 & 17.15 & 16.60 & 16.47 & 16.97 & 16.57 & 17.59 & 18.20 & 18.20 & 17.13 & 15.82 & 16.12 & 16.78 \\
\hline 18 & Ireland & 16.10 & 13.91 & 14.22 & 16.17 & 16.52 & 16.70 & 16.42 & 16.80 & 17.91 & 21.26 & 22.64 & 21.49 & 18.59 & 17.22 & 15.92 & 17.46 \\
\hline 19 & Iran & 19.10 & 21.50 & 20.68 & 17.62 & 13.23 & 17.67 & 16.82 & 22.13 & 14.38 & 16.64 & 20.72 & 20.16 & 16.82 & 16.40 & 16.54 & 18.03 \\
\hline 20 & Jordan & 19.40 & 21.92 & 20.47 & 19.29 & 17.31 & 17.45 & 16.96 & 19.28 & 17.34 & 17.35 & 17.37 & 16.55 & 17.28 & 17.72 & 16.09 & 18.12 \\
\hline 21 & Chile & 19.90 & 17.85 & 18.33 & 18.37 & 19.08 & 17.39 & 17.23 & 16.76 & 18.50 & 20.52 & 20.34 & 20.21 & 18.30 & 19.19 & 19.42 & 18.76 \\
\hline 22 & Sweden & 19.60 & 17.64 & 17.86 & 18.38 & 19.73 & 19.60 & 19.40 & 18.50 & 18.19 & 18.76 & 20.30 & 19.12 & 18.73 & 18.93 & 19.36 & 18.94 \\
\hline 23 & Finland & 18.40 & 17.74 & 16.70 & 17.72 & 18.75 & 18.74 & 18.96 & 17.88 & 17.55 & 19.16 & 21.08 & 20.81 & 19.93 & 20.94 & 21.28 & 19.04 \\
\hline 24 & Denmark & 18.40 & 17.54 & 17.90 & 18.29 & 18.60 & 18.78 & 17.81 & 17.77 & 18.24 & 19.46 & 21.73 & 21.84 & 20.22 & 20.19 & 19.85 & 19.11 \\
\hline 25 & $\begin{array}{l}\text { Hong Kong SAR, } \\
\text { China }\end{array}$ & 17.00 & 14.47 & 19.71 & 23.09 & 23.09 & 19.91 & 17.39 & 16.93 & 16.95 & 19.74 & 20.15 & 20.23 & 17.65 & 19.38 & 21.04 & 19.12 \\
\hline 26 & Czech Republic & 19.30 & 18.98 & 18.17 & 20.58 & 20.95 & 20.29 & 19.59 & 17.27 & 16.72 & 18.14 & 20.22 & 20.52 & 18.94 & 18.57 & 18.60 & 19.12 \\
\hline 27 & Norway & 19.20 & 18.48 & 20.08 & 20.89 & 20.89 & 20.41 & 19.20 & 17.51 & 17.98 & 18.30 & 20.38 & 20.60 & 19.90 & 20.03 & 19.77 & 19.58 \\
\hline 28 & Indonesia & 19.70 & 22.55 & 21.80 & 21.33 & 21.98 & 23.88 & 19.91 & 20.04 & 17.23 & 18.05 & 19.31 & 16.61 & 17.40 & 17.93 & 19.36 & 19.80 \\
\hline 29 & Mongolia & 18.40 & 20.30 & 22.81 & 21.63 & 21.23 & 22.96 & 19.27 & 20.91 & 20.46 & 21.76 & 19.69 & 19.40 & 17.33 & 16.87 & 19.48 & 20.17 \\
\hline 30 & Slovak Republic & 18.90 & 22.12 & 19.63 & 18.34 & 24.16 & 20.34 & 19.32 & 17.46 & 17.03 & 20.38 & 25.27 & 24.66 & 22.63 & 21.29 & 21.55 & 20.87 \\
\hline 31 & Israel & 22.70 & 22.61 & 23.17 & 24.04 & 23.87 & 21.44 & 20.35 & 19.93 & 19.72 & 20.00 & 19.47 & 19.70 & 19.41 & 19.87 & 20.58 & 21.12 \\
\hline 32 & India & 23.20 & 23.50 & 21.62 & 20.70 & 21.25 & 20.79 & 20.31 & 21.19 & 20.07 & 20.98 & 21.57 & 21.11 & 19.92 & 21.52 & 20.96 & 21.25 \\
\hline 33 & Maldives & 30.30 & 34.90 & 25.50 & 25.38 & 22.69 & 24.65 & 24.37 & 24.28 & 22.16 & 19.30 & 16.00 & 15.32 & 16.36 & 18.17 & 17.76 & 22.48 \\
\hline 34 & Mauritius & 23.30 & 21.19 & 21.06 & 21.73 & 25.69 & 25.26 & 24.69 & 22.98 & 18.97 & 19.47 & 22.55 & 23.18 & 23.99 & 22.93 & 23.88 & 22.72 \\
\hline 35 & Belgium & 22.70 & 20.21 & 22.12 & 23.03 & 24.14 & 23.43 & 23.14 & 22.08 & 21.79 & 23.48 & 24.53 & 24.34 & 23.94 & 25.14 & 26.11 & 23.35 \\
\hline 36 & Argentina & 25.20 & 28.12 & 29.62 & 25.36 & 22.76 & 15.64 & 17.69 & 18.22 & 20.32 & 22.83 & 26.70 & 26.77 & 27.41 & 33.33 & 34.67 & 24.98 \\
\hline 37 & Spain & 23.00 & 18.13 & 19.09 & 20.31 & 22.48 & 21.44 & 22.02 & 21.46 & 25.11 & 29.82 & 32.05 & 32.06 & 29.99 & 28.93 & 29.30 & 25.01 \\
\hline 38 & Portugal & 23.00 & 23.33 & 24.32 & 25.99 & 26.22 & 26.09 & 26.57 & 25.58 & 24.13 & 25.52 & 26.60 & 27.38 & 27.63 & 26.23 & 26.70 & 25.69 \\
\hline 39 & $\begin{array}{l}\text { United Arab } \\
\text { Emirates }\end{array}$ & 26.30 & 23.78 & 27.40 & 30.14 & 27.61 & 30.06 & 25.43 & 23.83 & 21.93 & 21.86 & 31.35 & 25.79 & 23.58 & 21.12 & 25.51 & 25.71 \\
\hline 40 & Hungary & 25.40 & 23.56 & 24.56 & 26.03 & 27.48 & 26.63 & 26.52 & 26.03 & 25.36 & 26.76 & 28.86 & 27.85 & 25.16 & 24.13 & 23.55 & 25.86 \\
\hline 41 & Latvia & 30.80 & 27.90 & 26.34 & 25.74 & 25.97 & 23.56 & 22.75 & 21.63 & 23.70 & 34.14 & 35.11 & 31.43 & 24.02 & 20.33 & 19.57 & 26.20 \\
\hline 42 & Poland & 27.70 & 33.76 & 32.28 & 29.28 & 29.39 & 26.12 & 22.90 & 21.15 & 20.31 & 23.71 & 27.79 & 29.11 & 28.05 & 27.01 & 26.86 & 27.03 \\
\hline 43 & Malta & 27.40 & 26.97 & 28.60 & 30.95 & 30.67 & 31.24 & 29.39 & 31.73 & 31.30 & 23.62 & 24.29 & 23.69 & 22.95 & 23.25 & 23.35 & 27.29 \\
\hline 44 & Estonia & 33.00 & 32.19 & 23.42 & 24.93 & 25.47 & 25.58 & 22.31 & 19.62 & 21.39 & 35.44 & 43.20 & 37.60 & 25.22 & 21.82 & 23.40 & 27.64 \\
\hline 45 & Slovenia & 27.30 & 26.45 & 26.01 & 27.77 & 28.12 & 27.24 & 27.50 & 26.08 & 24.99 & 26.57 & 29.44 & 30.72 & 30.61 & 30.94 & 30.64 & 28.02 \\
\hline 46 & Lithuania & 33.80 & 35.55 & 28.98 & 28.52 & 24.21 & 24.21 & 23.01 & 23.18 & 24.48 & 33.24 & 39.09 & 34.58 & 25.73 & 21.52 & 21.75 & 28.12 \\
\hline 47 & Bahamas, The & 26.30 & 25.08 & 27.18 & 28.72 & 28.88 & 27.06 & 23.20 & 23.41 & 23.46 & 30.70 & 33.80 & 34.33 & 28.80 & 29.17 & 32.66 & 28.18 \\
\hline 48 & Croatia & 33.80 & 36.86 & 29.93 & 26.67 & 22.34 & 25.64 & 25.26 & 23.35 & 24.46 & 25.40 & 30.22 & 30.97 & 32.08 & 31.86 & 31.20 & 28.67 \\
\hline 49 & Italy & 27.80 & 25.48 & 26.04 & 26.52 & 27.15 & 27.42 & 27.19 & 28.51 & 27.65 & 29.56 & 32.28 & 30.97 & 31.88 & 32.54 & 32.76 & 28.92 \\
\hline 50 & Namibia & 31.40 & 30.39 & 28.46 & 25.85 & 26.22 & 26.79 & 26.59 & 25.22 & 33.08 & 34.11 & 32.99 & 27.30 & 21.89 & 30.01 & 33.56 & 28.92 \\
\hline 51 & South Africa & 28.40 & 28.66 & 29.39 & 28.62 & 27.47 & 27.31 & 28.14 & 27.05 & 27.60 & 29.61 & 30.96 & 31.78 & 30.94 & 30.14 & 30.53 & 29.11 \\
\hline 52 & Yemen, Rep. & 27.70 & 27.78 & 26.97 & 24.18 & 23.38 & 23.07 & 20.67 & 25.95 & 25.79 & 28.67 & 32.11 & 36.73 & 38.66 & 38.70 & 41.00 & 29.42 \\
\hline 53 & Colombia & 39.40 & 35.79 & 32.39 & 28.21 & 27.91 & 26.32 & 27.25 & 24.62 & 28.13 & 28.45 & 32.31 & 29.57 & 28.44 & 28.16 & 28.85 & 29.72 \\
\hline
\end{tabular}




\begin{tabular}{|c|c|c|c|c|c|c|c|c|c|c|c|c|c|c|c|c|c|}
\hline 54 & $\begin{array}{l}\text { Trinidad and } \\
\text { Tobago }\end{array}$ & 34.70 & 25.94 & 30.07 & 29.62 & 27.41 & 24.66 & 26.60 & 29.56 & 25.91 & 28.11 & 36.15 & 35.22 & 31.74 & 32.32 & 32.40 & 30.03 \\
\hline 55 & Fiji & 32.90 & 32.71 & 33.86 & 32.48 & 30.76 & 28.44 & 29.34 & 38.00 & 36.35 & 32.88 & 28.61 & 26.70 & 24.40 & 25.93 & 25.28 & 30.58 \\
\hline 56 & Mexico & 30.80 & 29.76 & 30.84 & 30.96 & 31.50 & 29.79 & 29.85 & 28.64 & 28.35 & 32.35 & 35.21 & 32.31 & 30.58 & 32.25 & 31.19 & 30.96 \\
\hline 57 & Lebanon & 34.10 & 35.00 & 32.16 & 36.03 & 34.45 & 31.82 & 31.20 & 32.29 & 27.97 & 28.32 & 27.58 & 26.96 & 28.08 & 27.02 & 31.42 & 30.96 \\
\hline 58 & Algeria & 34.20 & 37.61 & 33.47 & 29.05 & 27.50 & 22.69 & 23.79 & 26.60 & 28.18 & 33.60 & 33.03 & 35.07 & 43.82 & 31.51 & 29.39 & 31.30 \\
\hline 59 & Costa Rica & 26.10 & 26.74 & 30.86 & 32.19 & 30.60 & 29.20 & 28.28 & 26.28 & 27.83 & 32.26 & 34.95 & 37.33 & 34.44 & 36.33 & 37.62 & 31.40 \\
\hline 60 & Korea, Rep. & 28.30 & 24.38 & 27.14 & 28.71 & 30.67 & 31.39 & 32.36 & 32.15 & 33.35 & 34.89 & 36.25 & 33.43 & 34.41 & 34.43 & 35.00 & 31.79 \\
\hline 61 & Pakistan & 37.00 & 31.34 & 29.05 & 29.92 & 30.79 & 28.89 & 27.23 & 27.69 & 30.65 & 32.68 & 33.75 & 35.69 & 32.22 & 35.20 & 36.90 & 31.93 \\
\hline 62 & Cyprus & 29.20 & 27.98 & 26.85 & 28.88 & 32.87 & 32.98 & 33.24 & 33.00 & 34.10 & 35.83 & 30.86 & 31.30 & 32.27 & 34.83 & 36.35 & 32.04 \\
\hline 63 & Greece & 28.50 & 27.42 & 27.22 & 29.52 & 28.71 & 28.20 & 29.51 & 28.72 & 30.02 & 31.19 & 37.09 & 39.39 & 43.97 & 45.06 & 28.50 & 32.20 \\
\hline 64 & Romania & 34.30 & 35.64 & 34.02 & 29.81 & 35.74 & 31.37 & 32.90 & 29.89 & 29.84 & 32.71 & 36.10 & 33.64 & 31.44 & 31.06 & 29.88 & 32.56 \\
\hline 65 & Venezuela, RB & 33.80 & 30.13 & 39.87 & 37.42 & 35.42 & 29.99 & 22.80 & 24.09 & 27.90 & 35.63 & 49.94 & 38.97 & 32.32 & 30.49 & 28.12 & 33.13 \\
\hline 66 & Bulgaria & 36.00 & 42.87 & 37.97 & 31.93 & 31.55 & 30.47 & 30.98 & 31.26 & 31.23 & 32.98 & 35.34 & 36.67 & 33.43 & 32.65 & 34.82 & 34.01 \\
\hline 67 & Bhutan & 29.60 & 37.39 & 35.90 & 34.58 & 34.73 & 35.15 & 37.05 & 36.69 & 33.33 & 33.63 & 34.95 & 31.67 & 31.10 & 33.10 & 33.02 & 34.13 \\
\hline 68 & Macedonia, FYR & 39.00 & 31.93 & 43.03 & 42.14 & 38.59 & 39.09 & 31.71 & 29.60 & 29.45 & 31.65 & 33.04 & 30.49 & 32.52 & 30.94 & 29.95 & 34.21 \\
\hline 69 & $\begin{array}{l}\text { Bosnia and } \\
\text { Herzegovina }\end{array}$ & 34.30 & 30.91 & 36.78 & 35.85 & 35.47 & 35.33 & 36.83 & 32.60 & 31.94 & 29.83 & 33.92 & 34.76 & 37.27 & 35.84 & 33.86 & 34.37 \\
\hline 70 & Cameroon & 33.30 & 31.74 & 33.16 & 33.04 & 31.86 & 34.13 & 32.63 & 31.73 & 32.48 & 33.65 & 40.78 & 37.41 & 43.03 & 38.35 & 38.39 & 35.05 \\
\hline 71 & Malaysia & 32.20 & 31.22 & 39.27 & 38.74 & 37.00 & 37.22 & 32.84 & 32.76 & 32.45 & 33.93 & 36.96 & 34.17 & 35.83 & 39.02 & 39.33 & 35.53 \\
\hline 72 & Turkey & 32.70 & 27.87 & 37.04 & 42.13 & 36.13 & 31.91 & 32.60 & 30.28 & 36.13 & 40.27 & 42.54 & 39.02 & 34.06 & 38.87 & 40.75 & 36.15 \\
\hline 73 & Serbia & 34.30 & 33.90 & 37.06 & 41.46 & 44.32 & 41.71 & 38.45 & 33.43 & 30.64 & 31.70 & 34.59 & 39.52 & 37.21 & 34.30 & 29.78 & 36.16 \\
\hline 74 & Ecuador & 34.20 & 39.11 & 38.21 & 33.82 & 29.51 & 28.61 & 30.08 & 27.93 & 31.39 & 35.76 & 43.28 & 42.33 & 40.44 & 44.01 & 45.88 & 36.30 \\
\hline 75 & Philippines & 43.80 & 45.78 & 44.76 & 38.48 & 37.43 & 29.80 & 32.03 & 27.87 & 34.93 & 33.30 & 35.08 & 34.96 & 34.34 & 37.47 & 37.07 & 36.47 \\
\hline 76 & Montenegro & 34.30 & 37.38 & 41.71 & 42.07 & 41.87 & 39.60 & 42.49 & 40.99 & 32.21 & 35.33 & 33.75 & 33.19 & 34.88 & 33.15 & 30.51 & 36.90 \\
\hline 77 & Morocco & 36.50 & 35.74 & 35.08 & 37.47 & 36.18 & 37.85 & 37.97 & 35.91 & 32.90 & 36.33 & 36.34 & 35.79 & 38.47 & 40.60 & 40.64 & 36.92 \\
\hline 78 & Bangladesh & 36.00 & 39.29 & 38.12 & 48.34 & 53.04 & 45.80 & 38.18 & 26.54 & 38.58 & 37.45 & 25.24 & 24.82 & 27.41 & 35.85 & 39.45 & 36.94 \\
\hline 79 & Egypt, Arab Rep. & 35.50 & 41.05 & 37.87 & 38.61 & 40.29 & 39.51 & 37.31 & 37.04 & 32.17 & 31.63 & 35.61 & 38.23 & 39.08 & 40.51 & 39.70 & 37.61 \\
\hline 80 & Paraguay & 38.00 & 44.20 & 49.41 & 37.44 & 36.32 & 25.54 & 36.42 & 32.07 & 32.99 & 34.00 & 41.30 & 38.87 & 38.47 & 47.34 & 49.39 & 38.78 \\
\hline 81 & Zambia & 49.30 & 50.15 & 48.90 & 45.66 & 44.26 & 42.57 & 40.63 & 37.99 & 36.70 & 34.88 & 31.28 & 30.70 & 32.92 & 32.57 & 36.21 & 39.65 \\
\hline 82 & Tunisia & 38.70 & 38.40 & 39.24 & 40.73 & 40.21 & 38.06 & 37.88 & 35.88 & 35.77 & 39.76 & 40.94 & 44.77 & 43.32 & 42.95 & 38.79 & 39.69 \\
\hline 83 & Brazil & 40.80 & 41.52 & 41.70 & 43.56 & 39.30 & 39.42 & 38.42 & 39.18 & 39.83 & 39.77 & 40.25 & 39.67 & 36.91 & 36.79 & 40.22 & 39.82 \\
\hline 84 & Jamaica & 36.40 & 36.19 & 35.48 & 34.79 & 32.44 & 33.20 & 36.91 & 36.79 & 41.91 & 45.91 & 48.45 & 45.44 & 44.86 & 47.05 & 45.47 & 40.09 \\
\hline 85 & Kyrgyz Republic & 41.40 & 41.28 & 43.90 & 43.21 & 34.85 & 33.80 & 37.32 & 36.73 & 37.90 & 37.91 & 39.60 & 40.63 & 41.62 & 48.20 & 46.51 & 40.32 \\
\hline 86 & Albania & 35.70 & 27.05 & 32.79 & 39.43 & 40.42 & 39.16 & 41.85 & 40.58 & 39.55 & 41.85 & 42.26 & 45.99 & 48.89 & 49.83 & 49.20 & 40.97 \\
\hline 87 & Cote d'Ivoire & 41.40 & 43.64 & 38.77 & 38.98 & 44.15 & 44.25 & 44.22 & 42.26 & 42.21 & 40.22 & 39.04 & 38.90 & 33.18 & 44.34 & 40.59 & 41.08 \\
\hline 88 & Barbados & 33.80 & 31.88 & 34.73 & 38.62 & 46.84 & 42.91 & 39.63 & 34.55 & 42.78 & 46.50 & 49.50 & 50.02 & 50.90 & 41.56 & 40.55 & 41.65 \\
\hline 89 & $\begin{array}{l}\text { Russian } \\
\text { Federation }\end{array}$ & 36.00 & 31.50 & 36.73 & 41.26 & 41.42 & 40.11 & 43.34 & 42.16 & 43.58 & 47.78 & 50.39 & 45.94 & 41.74 & 44.76 & 46.75 & 42.23 \\
\hline 90 & Kazakhstan & 43.80 & 38.61 & 41.82 & 39.29 & 42.52 & 48.06 & 36.20 & 33.81 & 40.81 & 39.62 & 46.64 & 44.05 & 45.80 & 50.97 & 48.97 & 42.73 \\
\hline 91 & Uganda & 43.50 & 50.69 & 49.61 & 53.90 & 51.69 & 39.11 & 47.91 & 46.01 & 47.29 & 39.05 & 33.89 & 33.93 & 45.03 & 31.86 & 33.86 & 43.16 \\
\hline 92 & Mali & 42.50 & 40.64 & 40.15 & 42.46 & 48.08 & 47.40 & 44.05 & 45.22 & 43.79 & 42.90 & 44.43 & 44.28 & 43.92 & 43.57 & 45.65 & 43.93 \\
\hline 93 & Armenia & 46.60 & 52.30 & 60.98 & 58.48 & 56.41 & 41.79 & 45.96 & 36.75 & 30.76 & 21.59 & 36.46 & 48.31 & 50.94 & 43.63 & 46.51 & 45.16 \\
\hline 94 & Madagascar & 40.10 & 46.56 & 47.67 & 40.27 & 38.67 & 35.88 & 41.11 & 47.47 & 60.37 & 48.45 & 45.53 & 48.79 & 48.28 & 44.38 & 46.32 & 45.32 \\
\hline 95 & Azerbaijan & 61.00 & 63.30 & 49.82 & 33.95 & 39.30 & 43.14 & 37.96 & 42.94 & 40.78 & 43.61 & 49.05 & 46.71 & 41.36 & 43.52 & 45.01 & 45.43 \\
\hline 96 & Cambodia & 50.40 & 49.35 & 44.02 & 51.26 & 50.82 & 42.43 & 34.06 & 25.16 & 41.85 & 44.12 & 49.78 & 53.59 & 50.98 & 52.58 & 51.98 & 46.16 \\
\hline 97 & Lao PDR & 30.90 & 30.84 & 36.97 & 32.84 & 34.02 & 37.06 & 40.90 & 41.88 & 46.35 & 53.74 & 57.70 & 52.14 & 54.87 & 67.58 & 75.96 & 46.25 \\
\hline 98 & Burundi & 39.10 & 32.95 & 34.62 & 33.52 & 38.61 & 41.82 & 41.57 & 43.26 & 58.53 & 62.98 & 58.70 & 66.45 & 57.72 & 52.64 & 48.96 & 47.43 \\
\hline 99 & Georgia & 34.00 & 20.77 & 26.16 & 31.15 & 29.06 & 41.38 & 52.51 & 42.44 & 63.96 & 80.99 & 76.42 & 61.57 & 55.66 & 56.12 & 52.29 & 48.30 \\
\hline 100 & Guinea & 39.70 & 40.81 & 41.20 & 50.13 & 43.86 & 39.28 & 39.83 & 49.80 & 38.98 & 49.07 & 53.94 & 72.15 & 57.98 & 56.02 & 53.94 & 48.45 \\
\hline 101 & Senegal & 45.00 & 48.43 & 39.19 & 43.21 & 44.64 & 51.19 & 49.00 & 48.28 & 48.46 & 47.51 & 52.05 & 54.43 & 52.51 & 57.50 & 52.30 & 48.91 \\
\hline 102 & Nicaragua & 45.70 & 48.98 & 47.60 & 48.54 & 52.47 & 52.91 & 46.40 & 47.24 & 49.19 & 51.91 & 56.03 & 55.07 & 49.45 & 41.09 & 41.15 & 48.92 \\
\hline 103 & EI Salvador & 46.50 & 48.84 & 52.60 & 46.67 & 46.23 & 47.55 & 45.40 & 49.33 & 44.36 & 49.41 & 52.28 & 53.98 & 52.43 & 52.83 & 57.01 & 49.70 \\
\hline 104 & Belize & 45.20 & 34.35 & 38.51 & 47.53 & 50.64 & 49.61 & 47.96 & 47.00 & 49.85 & 55.13 & 57.47 & 61.64 & 56.25 & 54.47 & 50.68 & 49.75 \\
\hline 105 & Tajikistan & 43.50 & 34.38 & 38.35 & 39.80 & 40.13 & 48.63 & 61.14 & 50.21 & 45.61 & 49.47 & 61.26 & 60.06 & 66.38 & 48.17 & 59.95 & 49.80 \\
\hline 106 & Sri Lanka & 45.20 & 46.15 & 46.31 & 57.88 & 55.15 & 53.67 & 55.73 & 64.45 & 61.15 & 66.11 & 71.91 & 56.70 & 38.24 & 27.94 & 17.47 & 50.94 \\
\hline 107 & Uruguay & 50.50 & 51.77 & 50.23 & 48.65 & 47.62 & 49.97 & 54.18 & 55.10 & 47.20 & 47.06 & 50.34 & 52.48 & 53.94 & 56.07 & 57.80 & 51.53 \\
\hline 108 & Ukraine & 52.70 & 53.79 & 49.70 & 47.28 & 48.47 & 46.34 & 50.69 & 51.59 & 52.12 & 50.54 & 58.97 & 59.07 & 51.43 & 52.30 & 51.48 & 51.76 \\
\hline
\end{tabular}




\begin{tabular}{|c|c|c|c|c|c|c|c|c|c|c|c|c|c|c|c|c|c|}
\hline 109 & Moldova & 36.00 & 28.04 & 44.49 & 55.48 & 56.46 & 50.01 & 49.49 & 60.60 & 55.47 & 63.68 & 75.84 & 74.47 & 64.99 & 66.13 & 59.56 & 56.05 \\
\hline 110 & Thailand & 53.40 & 47.32 & 47.13 & 50.61 & 52.01 & 52.95 & 55.61 & 54.68 & 56.45 & 59.05 & 60.76 & 60.25 & 63.03 & 64.93 & 70.13 & 56.55 \\
\hline 111 & Liberia & 44.20 & 42.96 & 40.09 & 28.41 & 30.93 & 56.45 & 56.16 & 52.86 & 65.05 & 82.64 & 68.40 & 69.06 & 72.58 & 79.90 & 85.64 & 58.36 \\
\hline 112 & Peru & 60.10 & 58.44 & 60.23 & 64.43 & 63.41 & 59.75 & 60.70 & 57.55 & 53.59 & 55.66 & 58.22 & 53.62 & 54.02 & 59.39 & 60.43 & 58.64 \\
\hline 113 & Benin & 51.20 & 50.26 & 52.62 & 54.18 & 59.47 & 58.13 & 58.91 & 58.25 & 59.60 & 64.58 & 68.63 & 68.86 & 66.42 & 68.29 & 67.98 & 60.49 \\
\hline 114 & Tanzania & 58.60 & 63.78 & 57.43 & 56.49 & 67.02 & 70.22 & 79.95 & 73.82 & 81.30 & 67.23 & 75.68 & 65.94 & 63.31 & 59.86 & 60.29 & 66.73 \\
\hline 115 & Guatemala & 51.6 & 55.9 & 76.2 & 84.8 & 79 & 68.7 & 55.4 & 57.1 & 59.7 & 66.1 & 68.2 & 71.3 & 71.2 & 74.6 & 72.3 & 67.46 \\
\hline 116 & Honduras & 50.30 & 56.62 & 64.10 & 67.20 & 68.54 & 70.21 & 63.94 & 60.07 & 71.60 & 77.21 & 84.81 & 81.73 & 72.71 & 69.38 & 72.62 & 68.74 \\
\hline \multirow[t]{2}{*}{117} & Bolivia & 67.00 & 70.59 & 71.51 & 74.54 & 71.96 & 72.28 & 78.37 & 69.43 & 64.09 & 59.48 & 70.74 & 75.50 & 72.63 & 65.63 & 65.32 & 69.94 \\
\hline & Time Average & 31.59 & 31.25 & 31.94 & 32.30 & 32.40 & 31.66 & 31.45 & 30.78 & 31.56 & 33.39 & 35.65 & 35.24 & 33.91 & 33.99 & 34.12 & 32.75 \\
\hline
\end{tabular}

\begin{tabular}{|c|c|c|c|c|c|}
\hline \multirow[t]{2}{*}{ Pos. } & \multirow{2}{*}{$\begin{array}{l}\text { Kinds of shadow economy activities } \\
\text { (rough estimates!) }\end{array}$} & \multicolumn{2}{|c|}{ Estonia } & \multicolumn{2}{|c|}{ Germany } \\
\hline & & $\begin{array}{l}\text { Size in \% of official GDP } \\
\text { average 2009-2015 }\end{array}$ & $\begin{array}{l}\text { Proportion of total } \\
\text { shadow economy }\end{array}$ & $\begin{array}{l}\text { Size in } \% \text { of official GDP } \\
\text { average } 2009-2015\end{array}$ & $\begin{array}{l}\text { Proportion of total } \\
\text { shadow economy }\end{array}$ \\
\hline 1 & $\begin{array}{l}\text { Total shadow economy (estimated by the MIMIC and } \\
\text { calibrated by the currency demand procedures) }\end{array}$ & 28.0 & $100 \%$ & 16.2 & $100 \%$ \\
\hline 2 & $\begin{array}{l}\text { Legally bought material for shadow economy and DIY } \\
\text { activities }\end{array}$ & 6.0 & $21 \%$ & 3.1 & $19.1 \%$ \\
\hline 3 & Illegal activities (smuggling etc.) & 2.0 & $7 \%$ & 1.2 & $7.4 \%$ \\
\hline \multirow[t]{2}{*}{4} & Do-it-yourself activities and neighbours' help1) & 2.0 & $7 \%$ & 1.5 & $9.2 \%$ \\
\hline & Sum (2) and (4) & 10.0 & $35 \%$ & 5.8 & $35.7 \%$ \\
\hline 5 & $\begin{array}{c}\text { "Adjusted" shadow economy (position (1) minus } \\
\text { position (5)) Without legally bought material which is } \\
\text { included in (2) }\end{array}$ & 18.0 & $65 \%$ & 10.2 & $64.3 \%$ \\
\hline
\end{tabular}

Table 5: Decomposition of the shadow economy activities in the Baltic countries: Example: Estonia and Germany.

\section{A critical discussion of the macro-MIMIC estimates}

As briefly and critically discussed in chapter 4 , macro estimates using the MIMIC and/or currency demand approach lead to quite high estimates of the shadow economy. One reason for this is that in the macro shadow economy estimates DIY (do-it-yourself) activities, neighbours and friends help and criminal activities (like smuggling, etc.) are (at least partly) included. We now try to consider this criticism and undertake an attempt to "correct" these macro estimates. In Table 5 such an attempt is undertaken for Estonia and Germany.

We argue that these corrections are rough approximations, but have a valid basis. First, we deduct legally bought material for shadow economy ${ }^{7}$ and do-it-yourself activities, this is done in line 2, varying between $19.1 \%$ and $21 \%$ of the macro estimates of shadow economy activities (100\%). Next, we subtract illegal activities (smuggling, drug dealing, etc.) which vary around $7 \%$ of total shadow economy activities, this is done in line 3. Finally, we deduct do-it-yourself activities and neighbours' and friends' help in line (4), varying between $7 \%$ and $9 \%$ between Estonia and Germany. If we sum these factors roughly $65 \%$ of the macro shadow economy size remains which should more accurately reflect the "true" size. We are aware that there are rough adjustments for which further research has to be done, but we think we can justify the adjusted values of the shadow economies of these 157 countries.

In Table 6 we show the averages for the shadow economies of the 157 large countries and of the117 small sample countries, where we included the self-employment variable in the MIMIC estimates. In this table we also include the adjusted shadow economy values for both country samples. Table 6 clearly shows that including the selfemployment variable has only a minor effect on the size of the shadow economy. Only for the lower countries do we see greater differences

${ }^{7}$ In some developing countries material is also illegal by being smuggled into the country, hence there may an interchange between legally bought material and smugglers, i.e., in developing countries the proportion of legally bought material may be smaller but smuggling will be higher. in the size of the shadow economy: Serbia has an average value of $36.16 \%$ with self- employment and $30.34 \%$ without self-employment; Singapore has an average value of $13.65 \%$ with self-employment and $13.44 \%$ without.

\section{Summary and Conclusion}

For the first time, our paper presents estimations of the shadow economy for 157 countries including developing, eastern European, central Asian and high income OECD countries from 1999 to 2013 using the MIMIC estimation method. According to our estimates the average size of the shadow economy (as a percentage of official GDP) of the 157 countries averaged over 1999 to 2013 is $33.77 \%$; for the 117 countries including self-employment data the average is $32.75 \%$. We also find that an increased burden of taxation combined with labor market regulations and institutional quality are driving forces of the shadow economy.

We are aware that these macro sizes of the shadow economy are quite high. Due to this, for the first time, we have tried to "correct" these macro estimates by subtracting legally bought material for shadow economy and do-it-yourself activities, illegal activities and doit-yourself activities; all three are included in the macro estimates by the MIMIC and/or currency demand approach. Our first calculations lead to an average reduction of the macro estimates of the shadow economy by $35 \%$ which in our opinion is plausible. Let us repeat, this is a first attempt and a rough calculation, where much more research is needed. The knowledge/insights with respect to the size of the shadow economy of 157 countries lead to the following three conclusions:

The first conclusion from these results is that for all countries investigated, the shadow economy has reached a large size, with an unweighted average of the shadow economy of $33.77 \%$ of official GDP for 157 countries from 1999 to 2007. We have no clear pattern of development over time, except that in most countries the shadow economies strongly rose in 2009 and 2010 due to the world economic 
Citation: Hassan Mai, Schneider Friedrich (2016) Size and Development of the Shadow Economies of 157 Worldwide Countries: Updated and New Measures from 1999 to 2013. J Glob Econ 4: 218. doi: 10.4172/2375-4389.1000218

Page 12 of 14

\begin{tabular}{|c|c|c|c|c|c|c|}
\hline \multirow[t]{2}{*}{ No. } & \multirow[t]{2}{*}{ Countryname } & \multicolumn{5}{|c|}{ Shadow Economies } \\
\hline & & $\begin{array}{l}\text { Averages based on } \\
\text { MIMIC 4-1-2 }\end{array}$ & $\begin{array}{c}\text { Averages base } \\
\text { MIMIC 5-1-2 } \\
\text { (incl. self-employm.) }\end{array}$ & Differences & $\begin{array}{c}\text { Adjusted averages based } \\
\text { on MIMIC 4-1-2 }\end{array}$ & $\begin{array}{l}\text { Adjusted averages based on } \\
\text { MIMIC 5-1-2 (incl. self-empl.) }\end{array}$ \\
\hline 1 & Albania & 42.12 & 40.97 & 1.15 & 27.38 & 26.63 \\
\hline 2 & Algeria & 32.77 & 31.30 & 1.47 & 21.30 & 20.35 \\
\hline 3 & Argentina & 26.17 & 24.98 & 1.19 & 17.01 & 16.23 \\
\hline 4 & Armenia & 45.57 & 45.16 & 0.41 & 29.62 & 29.36 \\
\hline 5 & Australia & 14.30 & 14.17 & 0.13 & 9.29 & 9.21 \\
\hline 6 & Austria & 9.83 & 9.84 & -0.01 & 6.39 & 6.39 \\
\hline 7 & Azerbaijan & 47.48 & 45.43 & 2.06 & 30.87 & 29.53 \\
\hline 8 & Bahamas, The & 26.71 & 28.18 & -1.47 & 17.36 & 18.32 \\
\hline 9 & Bahrain & 13.09 & 13.22 & -0.12 & 8.51 & 8.59 \\
\hline 10 & Bangladesh & 38.83 & 36.94 & 1.88 & 25.24 & 24.01 \\
\hline 11 & Barbados & 40.80 & 41.65 & -0.85 & 26.52 & 27.07 \\
\hline 12 & Belgium & 23.08 & 23.35 & -0.27 & 15.00 & 15.18 \\
\hline 13 & Belize & 50.83 & 49.75 & 1.08 & 33.04 & 32.34 \\
\hline 14 & Benin & 60.55 & 60.49 & 0.06 & 39.36 & 39.32 \\
\hline 15 & Bhutan & 34.28 & 34.13 & 0.15 & 22.28 & 22.18 \\
\hline 16 & Bolivia & 72.30 & 69.94 & 2.36 & 47.00 & 45.46 \\
\hline 17 & $\begin{array}{l}\text { Bosnia and } \\
\text { Herzegovina }\end{array}$ & 36.10 & 34.37 & 1.73 & 23.47 & 22.34 \\
\hline 18 & Brazil & 40.58 & 39.82 & 0.76 & 26.38 & 25.88 \\
\hline 19 & Bulgaria & 34.72 & 34.01 & 0.71 & 22.57 & 22.11 \\
\hline 20 & Burundi & 47.49 & 47.43 & 0.06 & 30.87 & 30.83 \\
\hline 21 & Cambodia & 49.21 & 46.16 & 3.06 & 31.99 & 30.00 \\
\hline 22 & Cameroon & 34.92 & 35.05 & -0.12 & 22.70 & 22.78 \\
\hline 23 & Canada & 16.17 & 16.37 & -0.20 & 10.51 & 10.64 \\
\hline 24 & Chile & 19.28 & 18.76 & 0.52 & 12.53 & 12.19 \\
\hline 25 & Colombia & 29.70 & 29.72 & -0.02 & 19.31 & 19.32 \\
\hline 26 & Costa Rica & 31.42 & 31.40 & 0.02 & 20.42 & 20.41 \\
\hline 27 & Cote d'Ivoire & 41.03 & 41.08 & -0.05 & 26.67 & 26.70 \\
\hline 28 & Croatia & 28.94 & 28.67 & 0.27 & 18.81 & 18.64 \\
\hline 29 & Cyprus & 31.99 & 32.04 & -0.04 & 20.80 & 20.82 \\
\hline 30 & Czech Republic & 18.95 & 19.12 & -0.17 & 12.32 & 12.43 \\
\hline 31 & Denmark & 19.04 & 19.11 & -0.07 & 12.38 & 12.42 \\
\hline 32 & Ecuador & 36.94 & 36.30 & 0.64 & 24.01 & 23.60 \\
\hline 33 & Egypt, Arab Rep. & 37.59 & 37.61 & -0.01 & 24.44 & 24.45 \\
\hline 34 & EI Salvador & 50.37 & 49.70 & 0.67 & 32.74 & 32.30 \\
\hline 35 & Estonia & 27.64 & 27.64 & 0.00 & 17.96 & 17.97 \\
\hline 36 & Fiji & 30.29 & 30.58 & -0.28 & 19.69 & 19.87 \\
\hline 37 & Finland & 18.81 & 19.04 & -0.23 & 12.22 & 12.38 \\
\hline 38 & France & 15.14 & 15.36 & -0.22 & 9.84 & 9.98 \\
\hline 39 & Georgia & 46.85 & 48.30 & -1.45 & 30.45 & 31.39 \\
\hline 40 & Germany & 15.77 & 15.79 & -0.03 & 10.25 & 10.26 \\
\hline 41 & Greece & 32.56 & 32.20 & 0.36 & 21.16 & 20.93 \\
\hline 42 & Guatemala & 67.68 & 67.46 & 0.21 & 43.99 & 43.85 \\
\hline 43 & Guinea & 47.87 & 48.45 & -0.58 & 31.12 & 31.49 \\
\hline 44 & Honduras & 68.17 & 68.74 & -0.57 & 44.31 & 44.68 \\
\hline 45 & $\begin{array}{l}\text { Hong Kong SAR, } \\
\text { China }\end{array}$ & 20.87 & 19.12 & 1.76 & 13.57 & 12.43 \\
\hline 46 & Hungary & 25.80 & 25.86 & -0.06 & 16.77 & 16.81 \\
\hline 47 & Iceland & 16.57 & 16.78 & -0.21 & 10.77 & 10.91 \\
\hline 48 & India & 21.76 & 21.25 & 0.51 & 14.14 & 13.81 \\
\hline 49 & Indonesia & 19.40 & 19.80 & -0.40 & 12.61 & 12.87 \\
\hline 50 & Iran, Islamic Rep. & 17.84 & 18.03 & -0.19 & 11.59 & 11.72 \\
\hline 51 & Ireland & 17.01 & 17.46 & -0.45 & 11.06 & 11.35 \\
\hline 52 & Israel & 21.23 & 21.12 & 0.11 & 13.80 & 13.73 \\
\hline 53 & Italy & 28.56 & 28.92 & -0.36 & 18.56 & 18.80 \\
\hline
\end{tabular}


Citation: Hassan Mai, Schneider Friedrich (2016) Size and Development of the Shadow Economies of 157 Worldwide Countries: Updated and New Measures from 1999 to 2013. J Glob Econ 4: 218. doi: 10.4172/2375-4389.1000218

Page 13 of 14

\begin{tabular}{|c|c|c|c|c|c|c|}
\hline 54 & Jamaica & 40.40 & 40.09 & 0.31 & 26.26 & 26.06 \\
\hline 55 & Japan & 13.81 & 13.46 & 0.35 & 8.97 & 8.75 \\
\hline 56 & Jordan & 18.37 & 18.12 & 0.25 & 11.94 & 11.78 \\
\hline 57 & Kazakhstan & 45.90 & 42.73 & 3.16 & 29.83 & 27.78 \\
\hline 58 & Korea, Rep. & 32.05 & 31.79 & 0.26 & 20.83 & 20.66 \\
\hline 59 & Kyrgyz Republic & 41.72 & 40.32 & 1.40 & 27.12 & 26.21 \\
\hline 60 & Lao PDR & 50.19 & 46.25 & 3.94 & 32.63 & 30.06 \\
\hline 61 & Latvia & 26.52 & 26.20 & 0.32 & 17.24 & 17.03 \\
\hline 62 & Lebanon & 31.71 & 30.96 & 0.75 & 20.61 & 20.12 \\
\hline 63 & Liberia & 57.11 & 58.36 & -1.24 & 37.12 & 37.93 \\
\hline 64 & Lithuania & 28.75 & 28.12 & 0.63 & 18.69 & 18.28 \\
\hline 65 & Luxembourg & 10.87 & 10.91 & -0.04 & 7.06 & 7.09 \\
\hline 66 & Macao SAR, China & 12.97 & 11.67 & 1.31 & 8.43 & 7.58 \\
\hline 67 & Macedonia, FYR & 34.11 & 34.21 & -0.10 & 22.17 & 22.24 \\
\hline 68 & Madagascar & 42.64 & 45.32 & -2.68 & 27.72 & 29.46 \\
\hline 69 & Malaysia & 35.32 & 35.53 & -0.21 & 22.96 & 23.09 \\
\hline 70 & Maldives & 23.33 & 22.48 & 0.85 & 15.16 & 14.61 \\
\hline 71 & Mali & 44.80 & 43.93 & 0.87 & 29.12 & 28.56 \\
\hline 72 & Malta & 26.80 & 27.29 & -0.49 & 17.42 & 17.74 \\
\hline 73 & Mauritius & 22.72 & 22.72 & -0.01 & 14.77 & 14.77 \\
\hline 74 & Mexico & 31.36 & 30.96 & 0.40 & 20.38 & 20.12 \\
\hline 75 & Moldova & 53.73 & 56.05 & -2.32 & 34.92 & 36.43 \\
\hline 76 & Mongolia & 21.66 & 20.17 & 1.49 & 14.08 & 13.11 \\
\hline 77 & Montenegro & 35.31 & 36.90 & -1.58 & 22.95 & 23.98 \\
\hline 78 & Morocco & 37.32 & 36.92 & 0.41 & 24.26 & 24.00 \\
\hline 79 & Namibia & 29.04 & 28.92 & 0.11 & 18.87 & 18.80 \\
\hline 80 & Netherlands & 14.69 & 14.98 & -0.30 & 9.55 & 9.74 \\
\hline 81 & New Zealand & 13.39 & 13.39 & 0.00 & 8.70 & 8.70 \\
\hline 82 & Nicaragua & 49.27 & 48.92 & 0.36 & 32.03 & 31.80 \\
\hline 83 & Norway & 20.01 & 19.58 & 0.43 & 13.00 & 12.72 \\
\hline 84 & Pakistan & 31.43 & 31.93 & -0.51 & 20.43 & 20.76 \\
\hline 85 & Paraguay & 40.62 & 38.78 & 1.84 & 26.41 & 25.21 \\
\hline 86 & Peru & 59.36 & 58.64 & 0.72 & 38.58 & 38.11 \\
\hline 87 & Philippines & 37.69 & 36.47 & 1.22 & 24.50 & 23.71 \\
\hline 88 & Poland & 26.97 & 27.03 & -0.06 & 17.53 & 17.57 \\
\hline 89 & Portugal & 25.43 & 25.69 & -0.26 & 16.53 & 16.70 \\
\hline 90 & Romania & 33.16 & 32.56 & 0.61 & 21.56 & 21.16 \\
\hline 91 & Russian Federation & 42.78 & 42.23 & 0.55 & 27.81 & 27.45 \\
\hline 92 & Senegal & 49.33 & 48.91 & 0.41 & 32.06 & 31.79 \\
\hline 93 & Serbia & 34.23 & 36.16 & -1.93 & 22.25 & 23.50 \\
\hline 94 & Singapore & 13.41 & 13.65 & -0.24 & 8.71 & 8.87 \\
\hline 95 & Slovak Republic & 22.11 & 20.87 & 1.24 & 14.37 & 13.57 \\
\hline 96 & Slovenia & 27.55 & 28.02 & -0.48 & 17.91 & 18.22 \\
\hline 97 & South Africa & 29.23 & 29.11 & 0.13 & 19.00 & 18.92 \\
\hline 98 & Spain & 24.61 & 25.01 & -0.40 & 16.00 & 16.26 \\
\hline 99 & Sri Lanka & 48.72 & 50.94 & -2.22 & 31.67 & 33.11 \\
\hline 100 & Sweden & 18.77 & 18.94 & -0.17 & 12.20 & 12.31 \\
\hline 101 & Switzerland & 9.09 & 9.03 & 0.07 & 5.91 & 5.87 \\
\hline 102 & Tajikistan & 51.67 & 49.80 & 1.87 & 33.59 & 32.37 \\
\hline 103 & Tanzania & 65.96 & 66.73 & -0.76 & 42.88 & 43.37 \\
\hline 104 & Thailand & 57.64 & 56.55 & 1.09 & 37.47 & 36.76 \\
\hline 105 & Trinidad and Tobago & 31.01 & 30.03 & 0.98 & 20.15 & 19.52 \\
\hline 106 & Tunisia & 39.85 & 39.69 & 0.15 & 25.90 & 25.80 \\
\hline 107 & Turkey & 37.33 & 36.15 & 1.17 & 24.26 & 23.50 \\
\hline 108 & Uganda & 43.61 & 43.16 & 0.45 & 28.34 & 28.05 \\
\hline 109 & Ukraine & 52.23 & 51.76 & 0.47 & 33.95 & 33.65 \\
\hline 110 & United Arab Emirates & 26.09 & 25.71 & 0.38 & 16.96 & 16.71 \\
\hline 111 & United Kingdom & 13.78 & 14.07 & -0.30 & 8.95 & 9.15 \\
\hline
\end{tabular}


Citation: Hassan Mai, Schneider Friedrich (2016) Size and Development of the Shadow Economies of 157 Worldwide Countries: Updated and New Measures from 1999 to 2013. J Glob Econ 4: 218. doi: 10.4172/2375-4389.1000218

Page 14 of 14

\begin{tabular}{|l|l|c|c|c|c|c|}
\hline 112 & United States & 9.17 & 9.35 & -0.19 & 5.96 \\
\hline $\mathbf{1 1 3}$ & Uruguay & 52.38 & 51.53 & 0.86 & 34.05 \\
\hline $\mathbf{1 1 4}$ & Venezuela, RB & 33.91 & 33.13 & 0.78 & 22.04 \\
\hline $\mathbf{1 1 5}$ & Vietnam & 17.17 & 15.55 & 1.62 & 11.16 \\
\hline $\mathbf{1 1 6}$ & Yemen, Rep. & 29.28 & 29.42 & -0.15 & 19.53 \\
\hline $\mathbf{1 1 7}$ & Zambia & 40.04 & 39.65 & 0.39 & 19.11 \\
\hline & Averages & 33.03 & 32.75 & 0.28 & 26.03 \\
\hline
\end{tabular}

Table 6: Summary table without and with adjustments.

and financial crises in 2008/2009. The same holds for the development of the size of shadow economies after 2009.

The second conclusion is that the shadow economy is present to an important extent in all types of economies (developing, transition and highly developed countries). People engage in shadow economy activities for very different reasons. However, the most important are government actions like taxation and regulations.

The third conclusion is that there are large regional disparities in the level of informality. At the top level of informality are South America and Africa. At the lowest level of informality are highly developed OECD countries.

Considering these three conclusions, it is obvious that every government needs to institute incentive-oriented economic policies in order to make work in the official economy more attractive. Successful implementation of such policy may lead to stabilization or even reduction in the size of the shadow economy over time.

Finally, even after 30 years of intensive research, the size, causes and consequences of the shadow economy are still controversially debated in the literature and further research is necessary to improve our understanding of the shadow economy. The question of the "correct" size of a shadow economy is an especially controversial topic. We make a first attempt in this paper to tackle this question and to demonstrate that the macro size, obtained by MIMIC and/or currency demand methods, needs to be corrected for legally bought material, crime activities and do-it-yourself activities.

\section{References}

1. Schneider F, Enste D (2002) The shadow economy: An international survey. Cambridge University Press, UK.

2. Schneider $F(2010)$ The influence of public institutions on the shadow economy: An empirical investigation for OECD countries. Review of Law and Economics 6: 113-140.

3. Williams CC, Schneider F (2016) Measuring the global shadow economy the prevalence of informal work and labour. Edward Elgar Publishing, UK.

4. Zellner A (1970) Estimation of regression relationships containing unobservable independent variables. International Economic Review 11: 441-454.

5. Joreskog KG, Goldberger AS (1975) Estimation of a model with multiple indicators and multiple causes of a single latent variable. Journal of the American Statistical Association 70: 631-639.

6. Farzanegan MR (2009) Illegal trade in the Iranian economy: Evidence from a structural model. Eur J Polit Econ 25: 489-507.

7. Schneider F, Buehn A, Montenegro CE (2010) New estimates for the shadow economies all over the world. Int Econ J 24: 443-461.

8. Feld L, Schneider F (2010) Survey on the shadow economy and undeclared earnings in OECD countries. Ger Econ Rev 11: 109-149.

9. Frey BS, Weck-Hanneman H (1984) The hidden economy as an "unobserved" variable. Eur Econ Rev 26: 33-53.

10. Tafenau E, Herwartz H, Schneider F (2010) Regional estimates of the shadow economy in Europe. Int Econ J 24: 629-636.
11. Tedds L (2005) The underground economy in Canada. Ashgate Publishing, UK.

12. Dell'Anno R (2007) The shadow economy in Portugal: An analysis with the MIMIC approach. J Appl Econ 2: 253-277

13. Hassan M, Schneider F (2016) Modelling egyptian shadow economy: A MIMIC model and a currency demand approach. Journal of Economics and Political Economy 3: 309-339.

14. Buehn A, Farzanegan MR (2013) Impact of education on the shadow economy: Institutions matter. Econ Bull 33: 2052-2063.

15. Chaudhuri K, Schneider F, Chattopadhyay S (2006) The size and development of the shadow economy: An empirical investigation from states of India. J Dev Econ 80: 428-443.

16. Tanzi $V(1999)$ Uses and abuses of estimates of the underground economy. Econ J 109: 338-347.

17. Alañón A, Gómez-Antonio M (2005) Estimating the size of the shadow economy in Spain: a structural model with latent variables. Appl Econ 37: 1011-1025.

18. Buehn A (2012) The shadow economy in German regions: An empirical assessment. Ger Econ Rev 13: 275-290.

19. Buehn A, Schneider F (2008) MIMIC Models, cointegration and error correction: an application to the french shadow economy. IZA Working Paper No. 3306.

20. Johnson, Simon Kauffman, Daniel Zoido-Lobaton P (1997) Regulatory discretion and the unofficiai economy. American Economic Review Papers and Proceedings 88: 387-393.

21. Loayza NV (1996) The economics of the informal sector: a simple model and some empirical evidence from Latin America. Carnegie-Rochester Conference Series on Public Policy 45: 129-162.

22. Dell'Anno R, Gómez-Antonio M, Pardo A (2007) The shadow economy in three Mediterranean countries: France, Spain and Greece. A MIMIC approach. Empir Econ 33: 51-84

23. Razmi MJ, Falahi MA, Montazeri S (2013) Institutional quality and underground economy of 51 OIC member countries. Universal Journal of Management and Social Sciences 3: 1-14.

24. Schneider F, Williams CC (2013) The shadow economy. The Institute of Economic Affairs, IEA, London, UK.

25. Bajada C, Schneider F (2005) The shadow economies of the Asia-Pacific. Pac Econ Rev 10: 379-401.

26. Bollen KA (1989) Structural equations with latent variables. Wiley, New York.

27. Buehn, Andreas, Karmann, Alexander, Schneider, et al. (2009) Shadow economy and do-it- yourself activities: the German case. J Inst Theoretical Econ 165: 701-722.

28. Schneider $F$ (2015) Size and development of the shadow economy of 31 European and 5 other OECD countries from 2003 to 2015: different developments.

29. Dell'Anno R, Schneider F (2009) A complex approach to estimate the shadow economy: the structural equation modelling. Coping with Complexity of Economics. Springer.

30. Satorra A, Bentler PM (1994) Corrections to test statistics and standard errors in covariance structure analysis. 